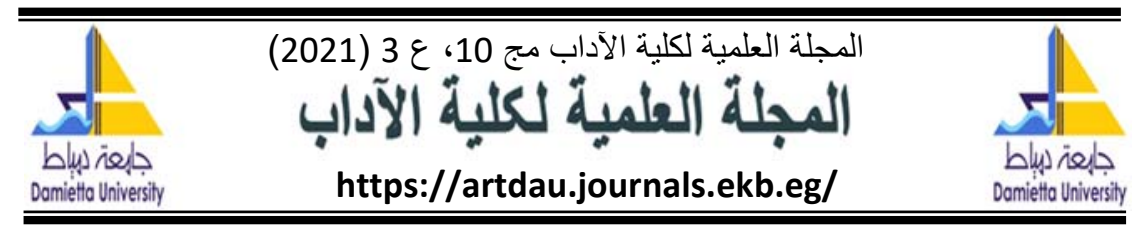

\title{
دور وسائل التواصل الاجتماعي في توعية المواطنين بالمبادرات الصحية
}

هاجر مجدي عبده الحمامي

طالبة ماجستير مجير - قسم الاعملام - كلية الآداب - جامعة دمياط.

\section{المستخلص الابل}

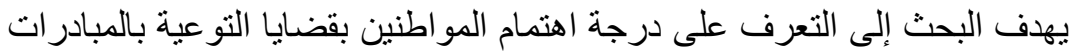

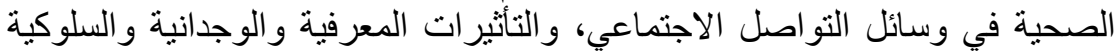

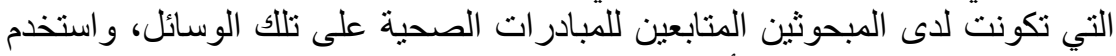
البحث منهج المسح بالعينة، و أداة الاستبيان لجمع البياناتيات، كما تمثلت عينة البحث على عينة

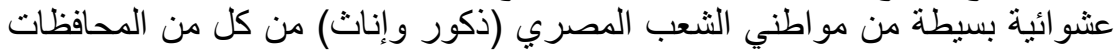

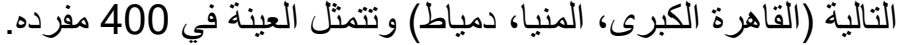

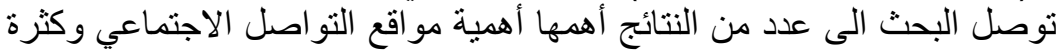

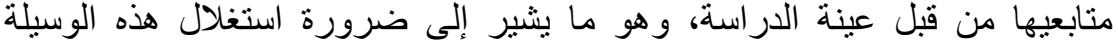
وتوظيفها في التوعية الصحية مما يعزز أهميتها، جاءت فئة (مواقع التواصل الصن الاجتماعي)

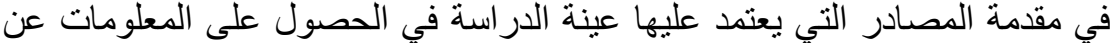

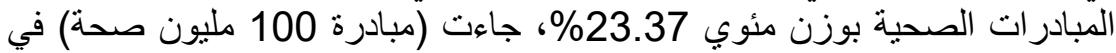

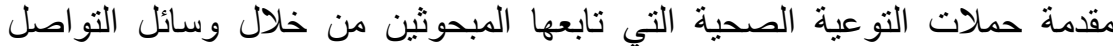

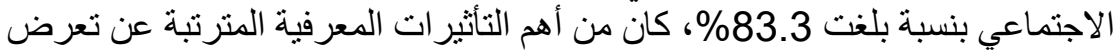

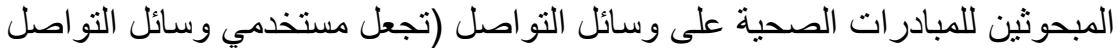

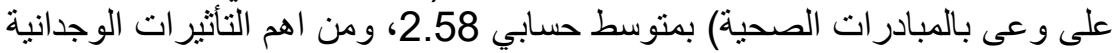

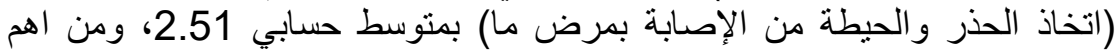
التأثير ات السلوكية (أقوم بتعديل سلوكي الصحي وفقا للمعلومات الصحية للصية للمبادر ات)

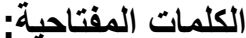

وسائل التو اصل الاجتماعي ، المبادر ات الصحية

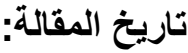

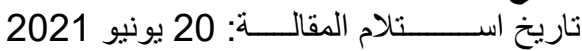
تاريخ استلام النسخة النهائية: 3 يوليو 2021 تئية

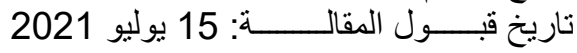




\section{1. مقدمة}

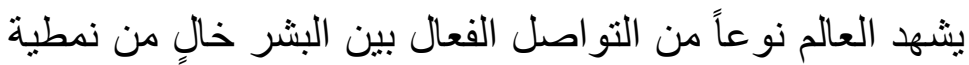

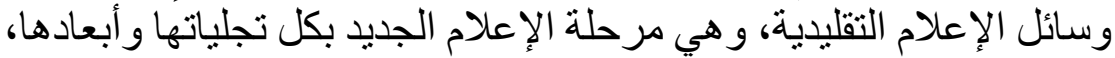

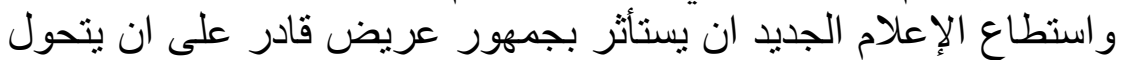

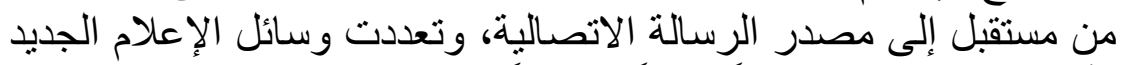

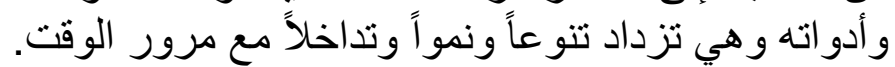

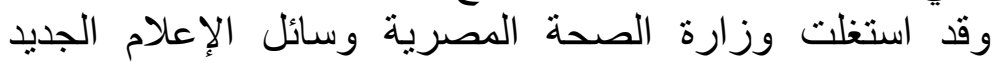

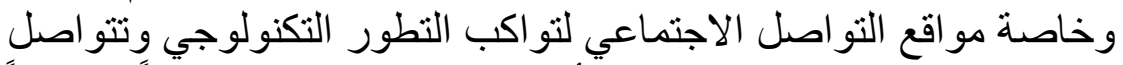

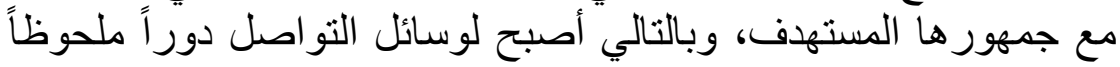

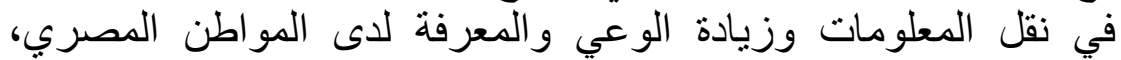

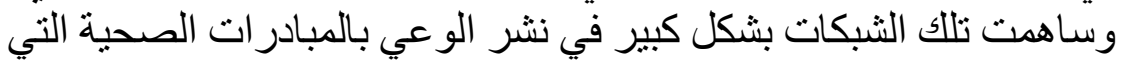

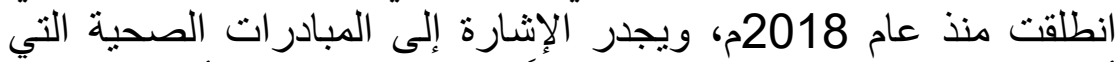

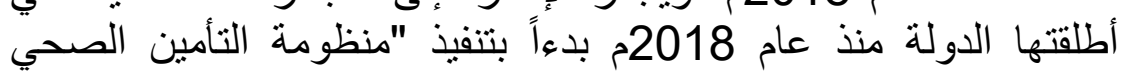

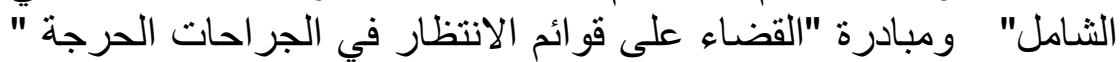

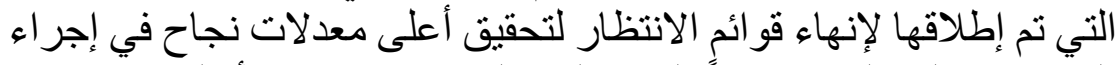

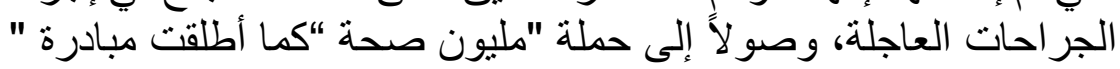

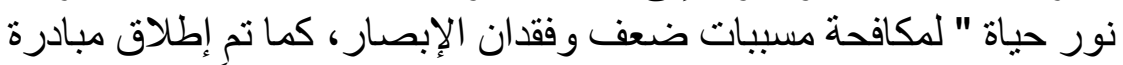

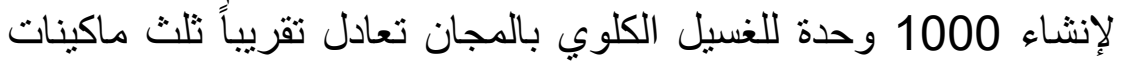

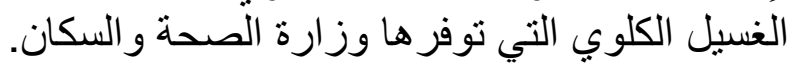

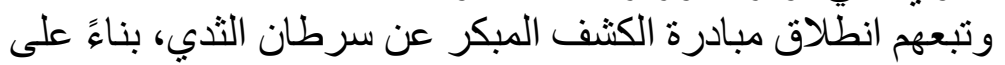

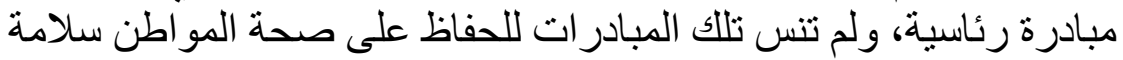

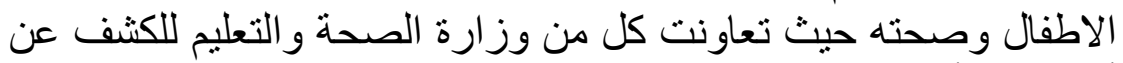

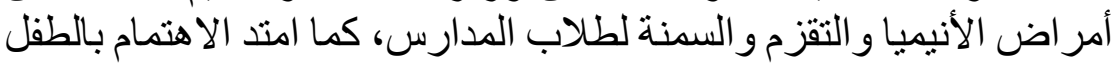

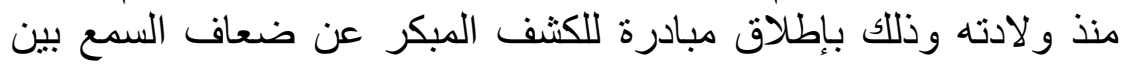

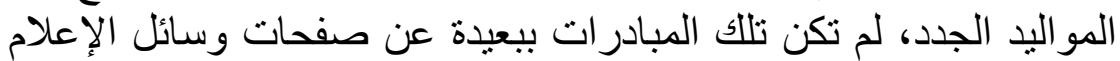

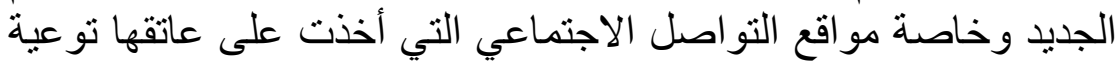

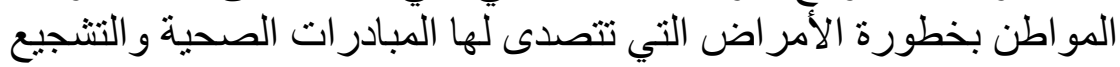

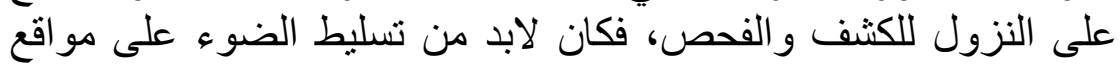

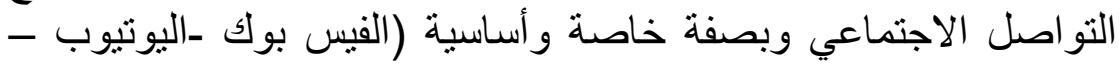
تويثر).

2. 2. 2. الدراسات السابقة

1.2 دراسات تناولت دور الإعلام الجديد في التوعية الصحية

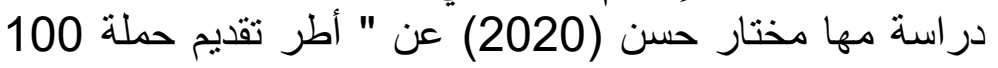
مليون صحة في المواقع الإخبارية المصرية". هدفت الدراسة إلى تلى رصد 


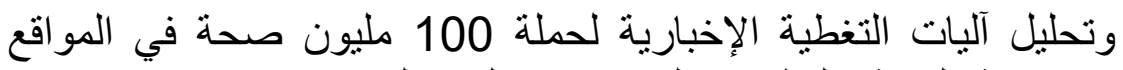

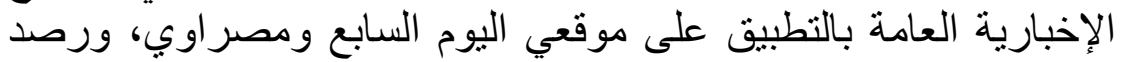

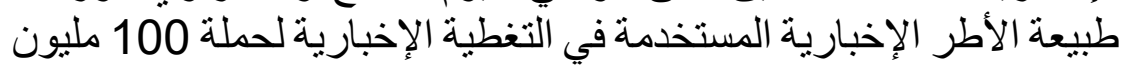

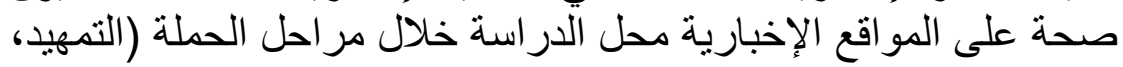

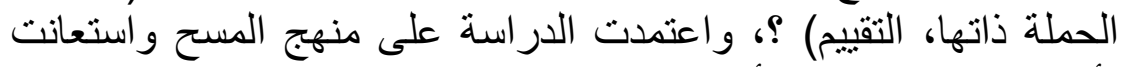

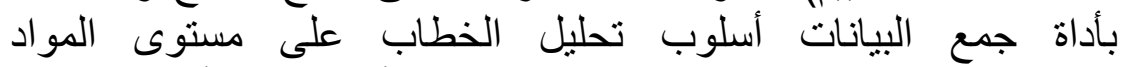

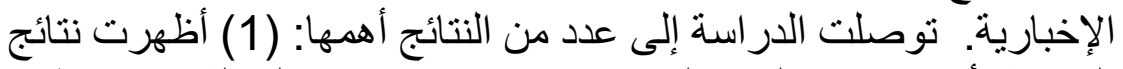

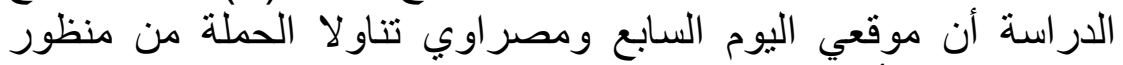

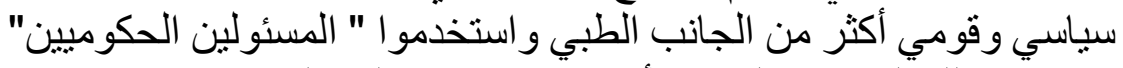

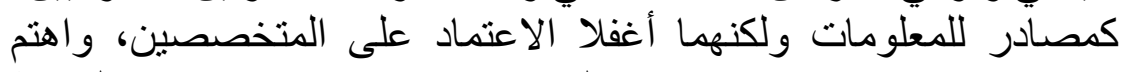

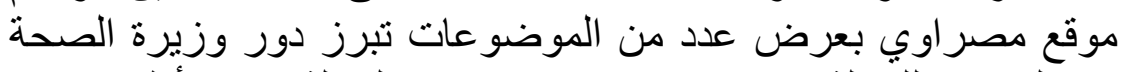

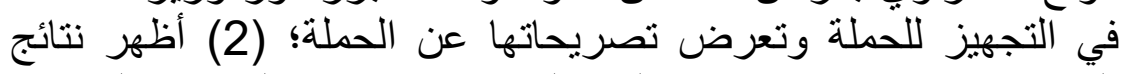

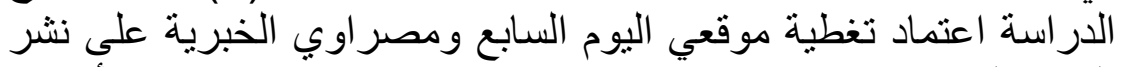
الخبر الصحفي بنسبة (93.07 \% \% و (97.6 \%) في متابعة أحداث

دراسة داليا عثمان إبراهيم (2019) عن "اتجاهات المرأة

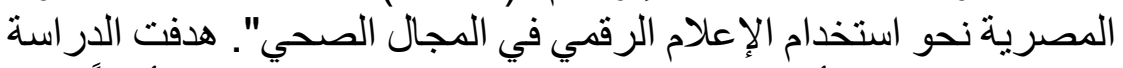

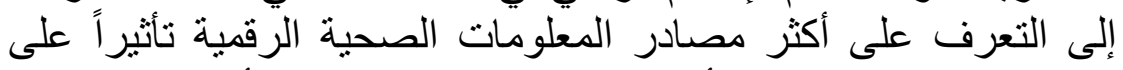

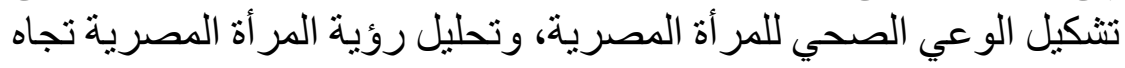

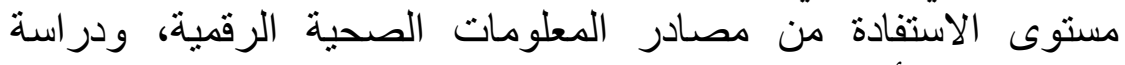

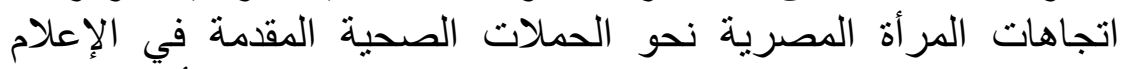

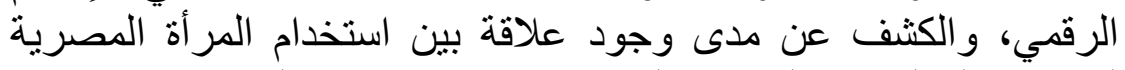

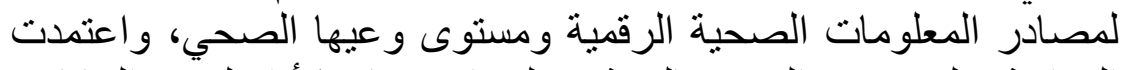

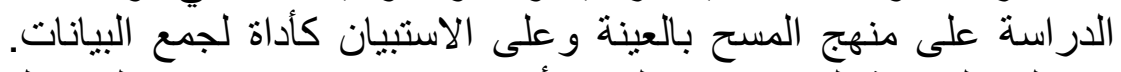

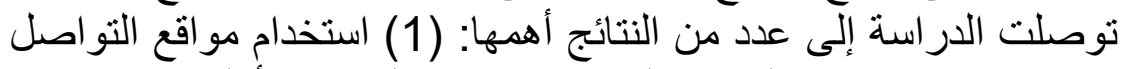

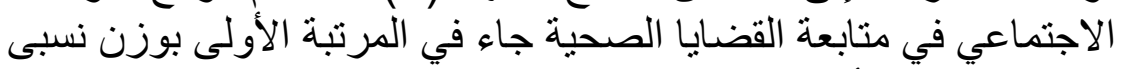

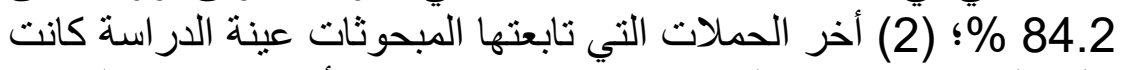

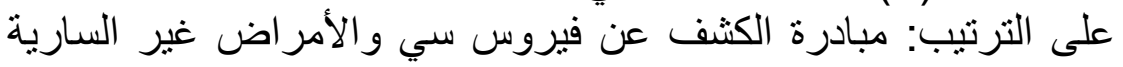

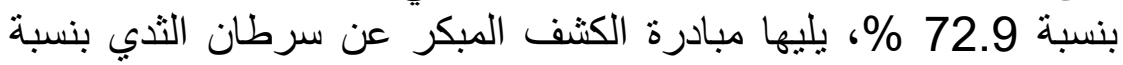

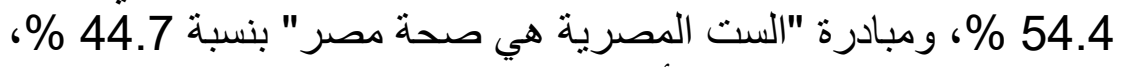

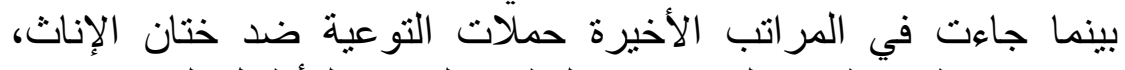

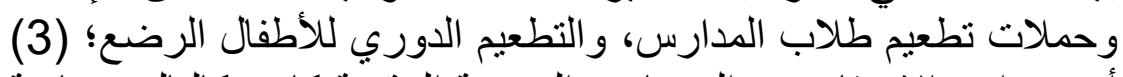

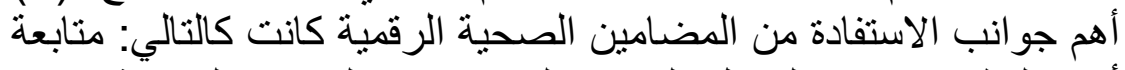
أخر التطورات في المجال الصحي لتزيد من معلوماتها الصحية بوزية الصنان

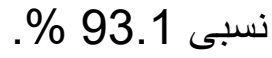




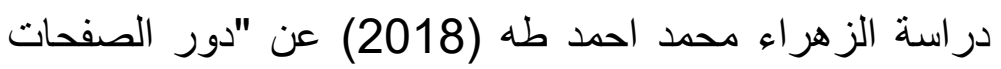

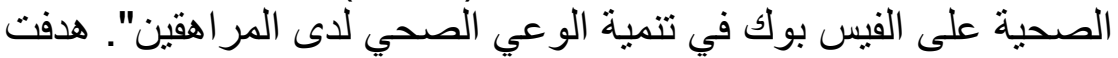

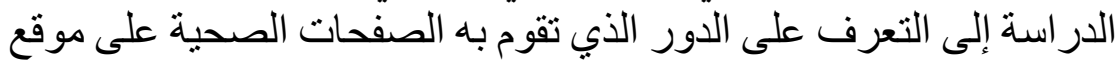

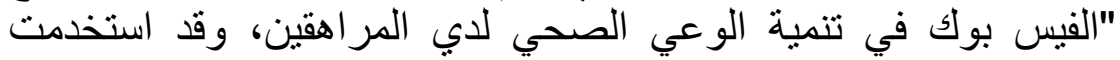

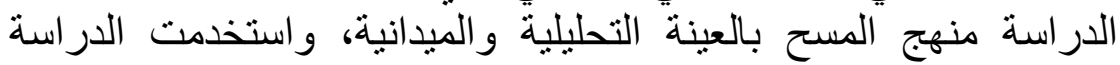

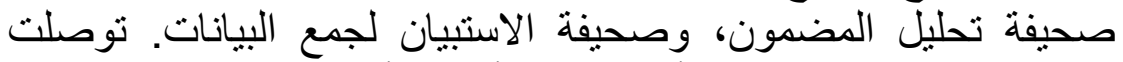

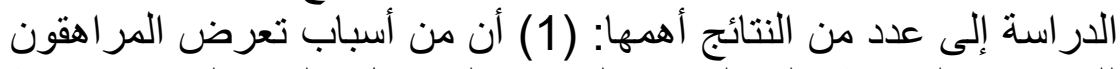

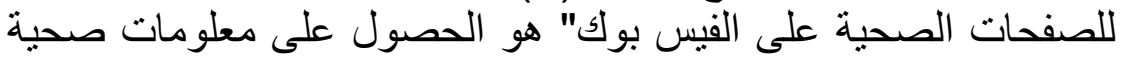

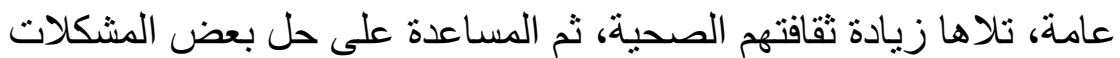

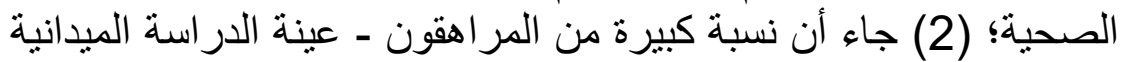

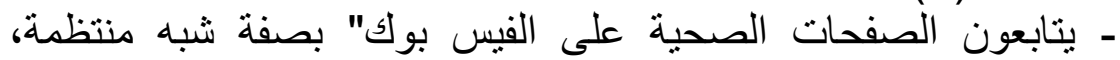
ويتعرضون لهذه الصفحات مرة كل عدة أسابيع.

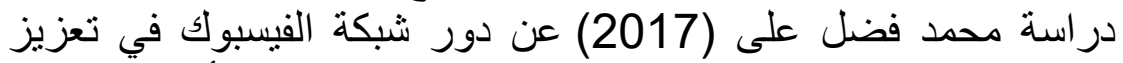

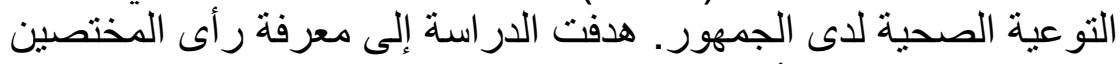

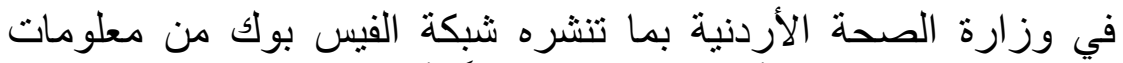

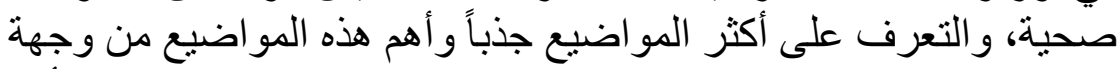

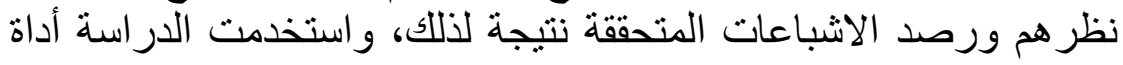

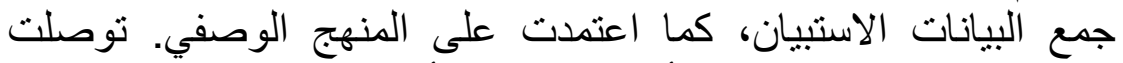

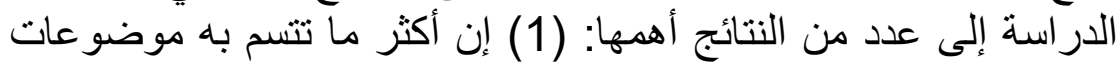

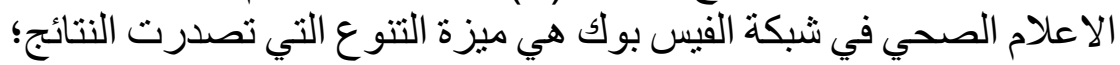

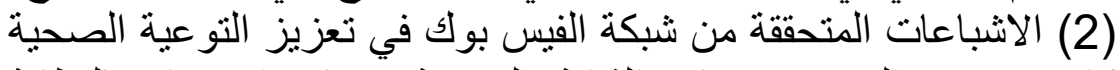

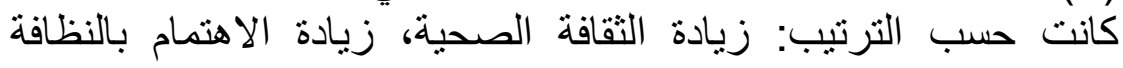

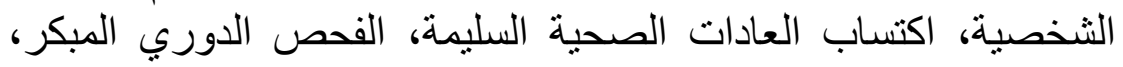

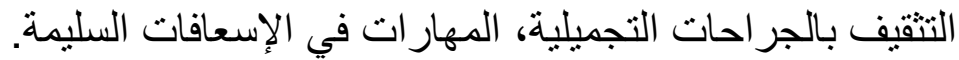

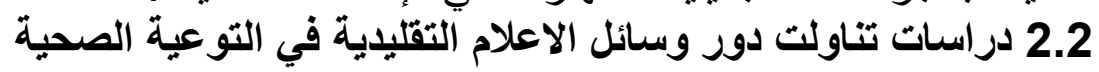

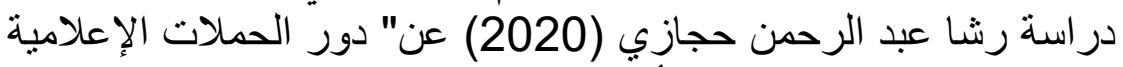

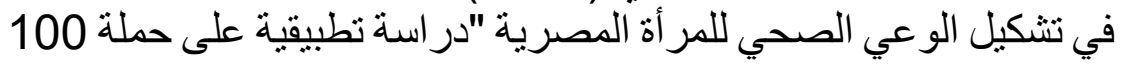

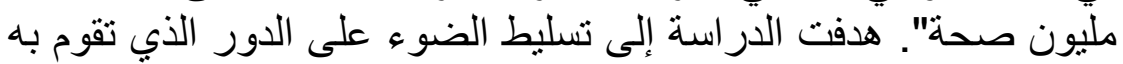

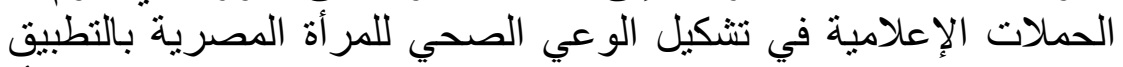

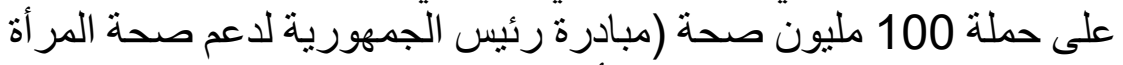

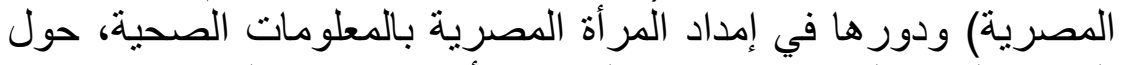

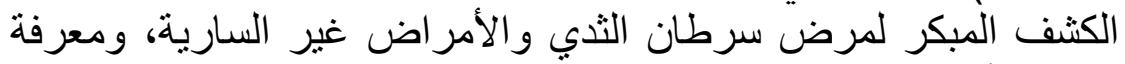

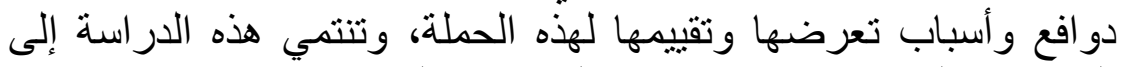

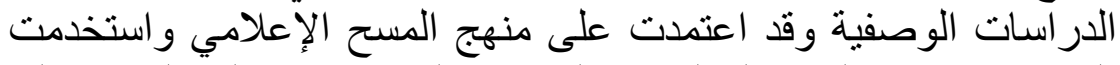

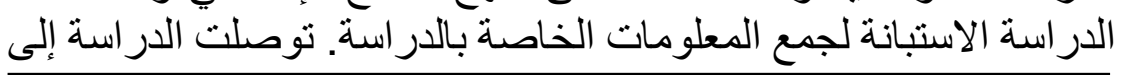




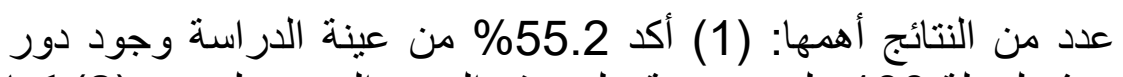

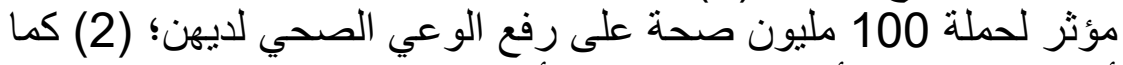

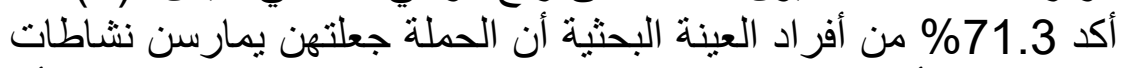

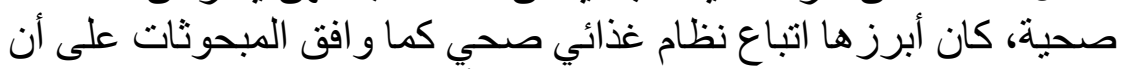

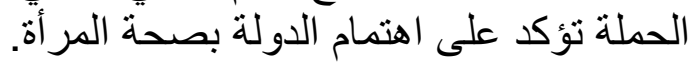

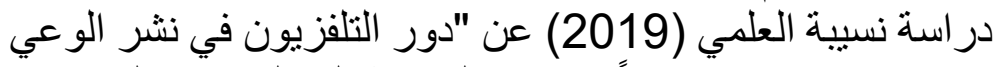

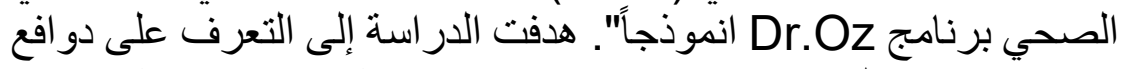

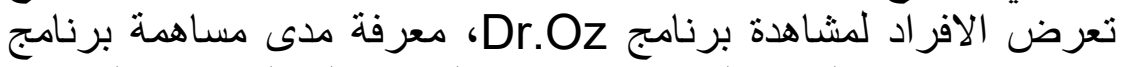
في نشر الوعي الصحي، و تنتمي الدراسة إلى الدراسات الوصنية الدئية

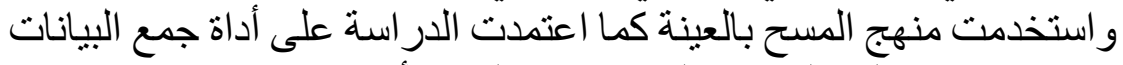

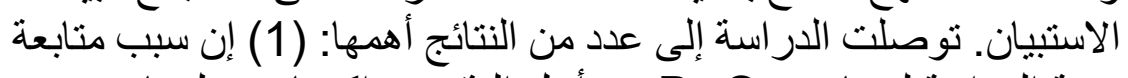

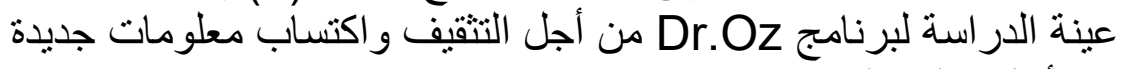

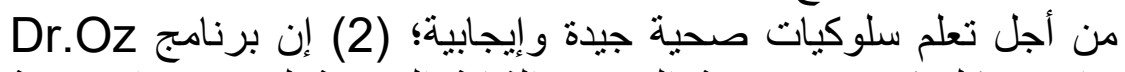
ساهم بشكل كبير في تنمية الوعي والثقافة الصحية لدى مفردات عينة

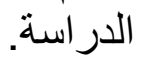

دراسة نور الهدى بن سماعيلى واميرة قدار (2018) عن "دور

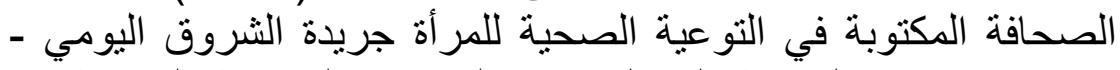

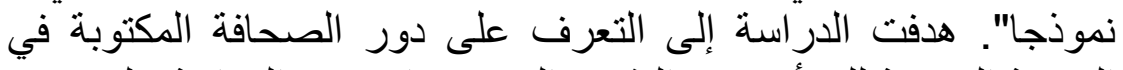

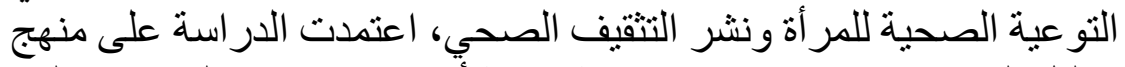

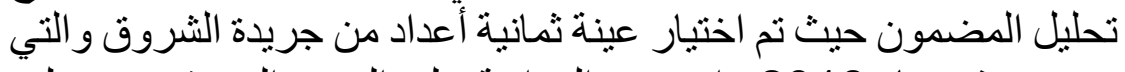

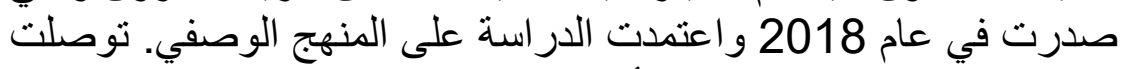

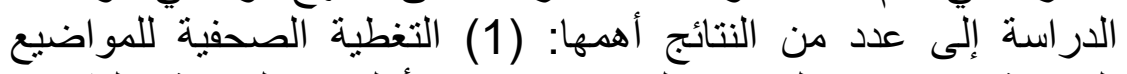

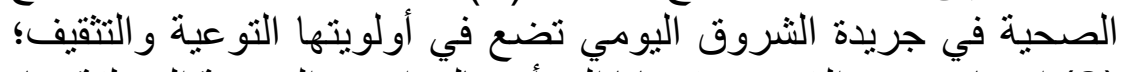

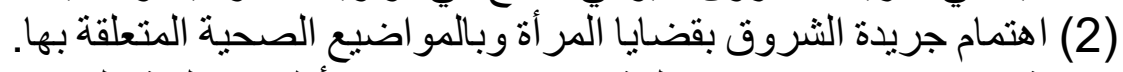

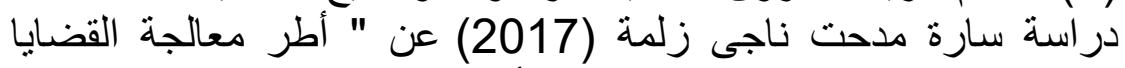

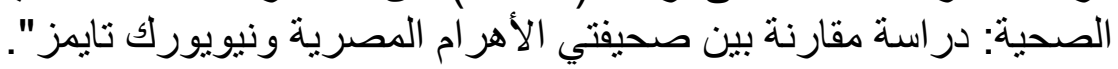

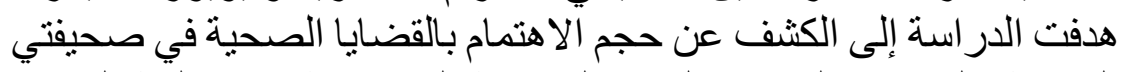

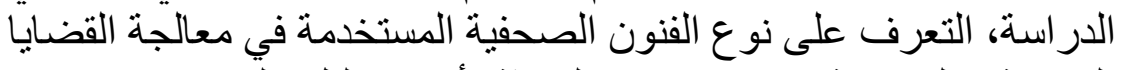

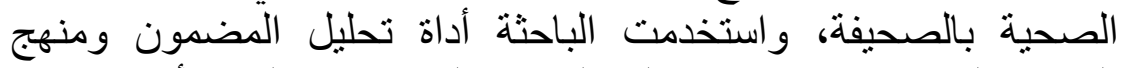

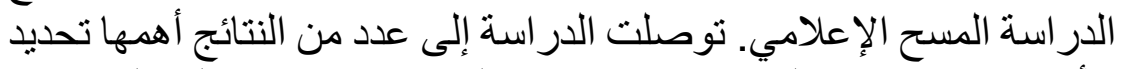

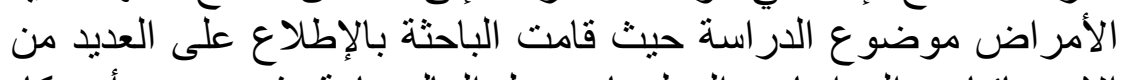

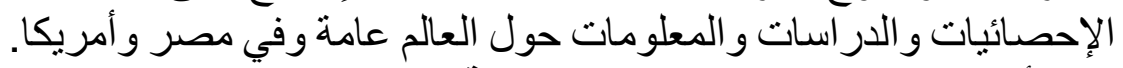
3.2 أوجه الاستفادة من الاراسات السات الدابقة

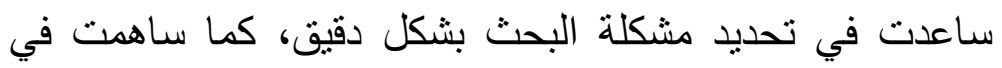
صياغة الفروض والتساؤلات بشكل سليم، واستفادت الباحثة من الدراسات 


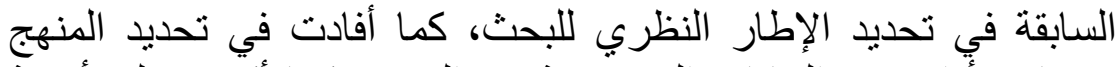

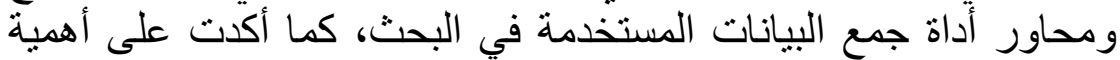

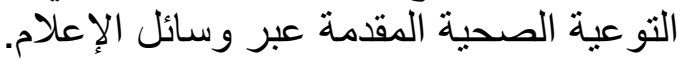
3 الإطار النظري للبحثة 13 1.3 نظرية الاعثماد على وسائل الإعلام

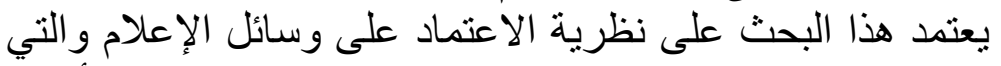

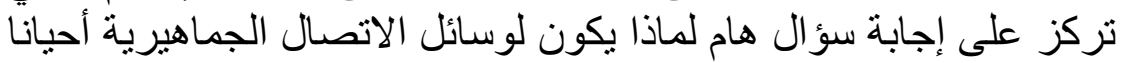

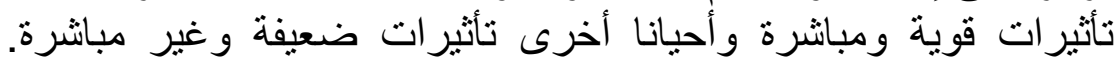

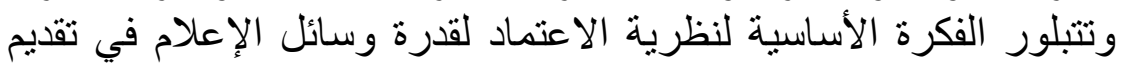

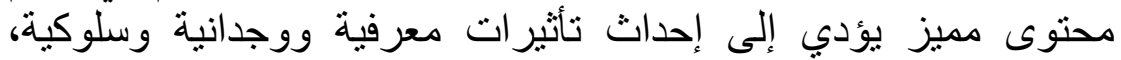

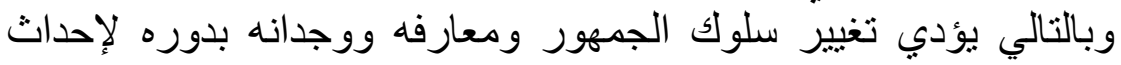
تغيير في المجنمع و الوسائل الإعلامية.

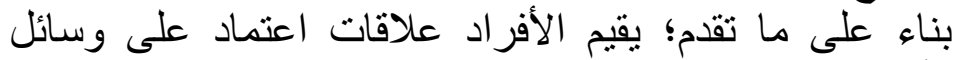

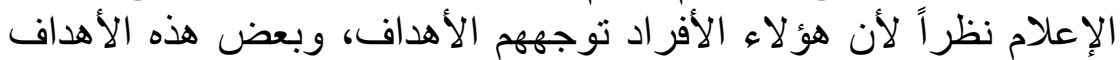

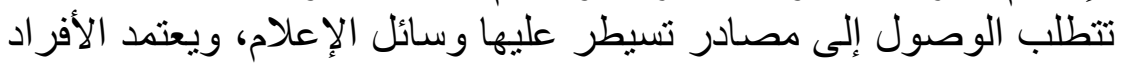
على وسائل الإعلام المختلفة لتحقيق الأهداف التالية:

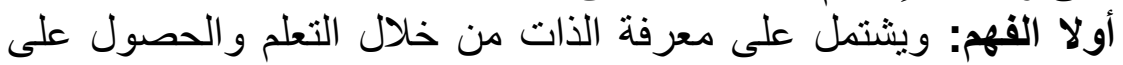
الخبر ات المختلفة، والفهم الاجتماعي من خلاعل معن معرفة أثنياء عن العالم أو البيئة أو الجماعة المحلية أو البيئة البئة المحيطة

$$
\text { وتفسير ها. }
$$

ثانيًا التوجيه: ويشتمل على توجيه العمل و السلوك في إطار التوقعات

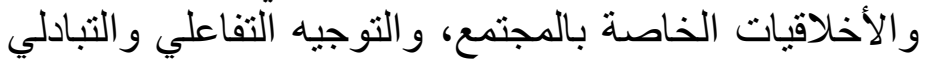

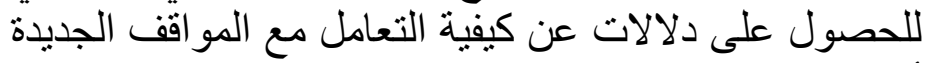

$$
\text { أو الصعبة. }
$$

ثالثا التسلية: وتشتمل على التسلية المنعزلة مثل: الراحة والاسترخاء

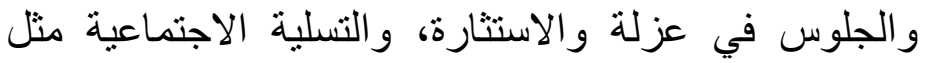

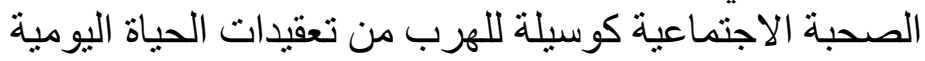

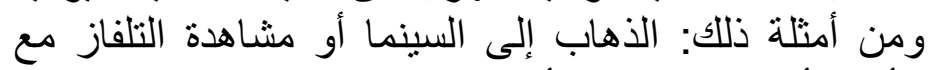

$$
\text { الأسرة أو الجلوس مع الأصدقاء. الذهاء. }
$$

1.1.3 فروض النظرية

تطر ح نظرية الاعتماد على وسائل الإعلام عدة افتر اضات إنات:

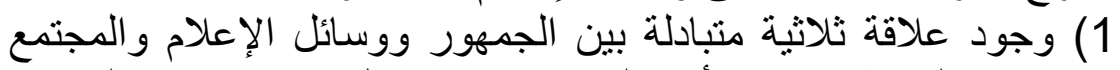

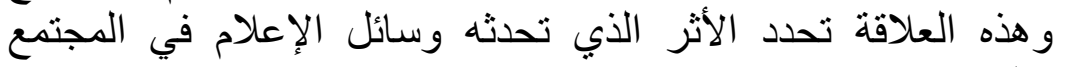


2) يزداد درجة اعتماد الأفر اد على وسائل الإعلام كلما كانت المعلومات

$$
\text { التي تبث عبر ها ذاد دات أهمية. }
$$

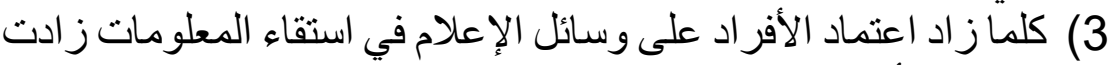

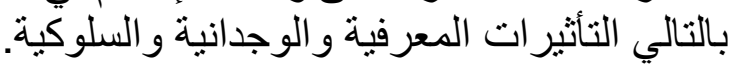

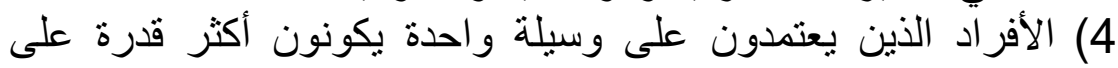

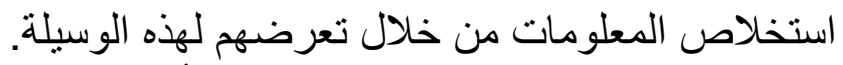

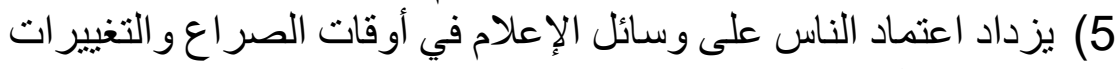

الاجتماعية.

6) يزداد درجة اعتماد الجمهور على وسائل الإعلام في حالة اثباع

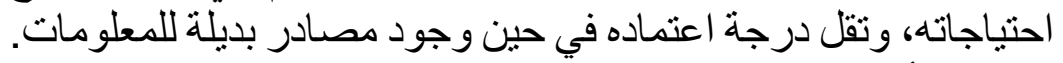

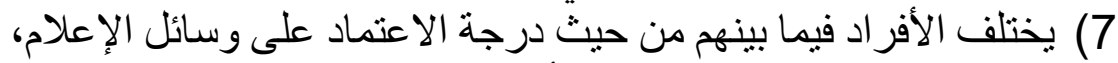

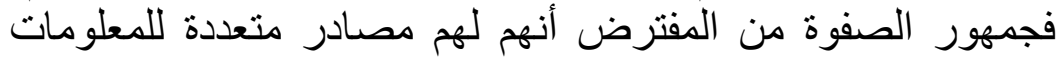

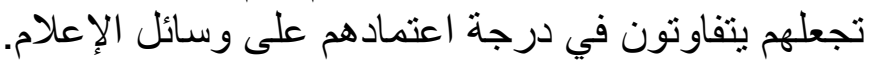

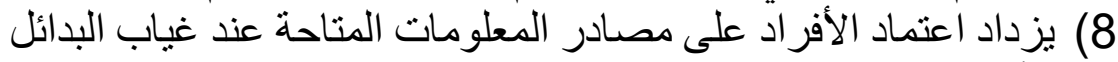

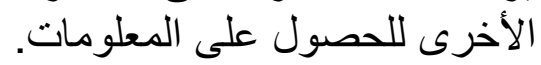

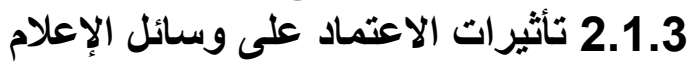

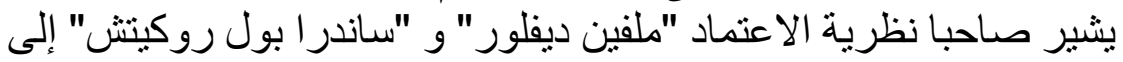

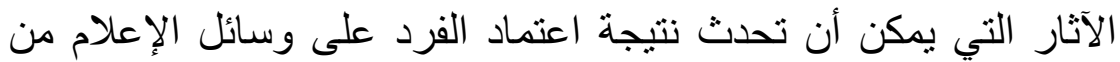
خلال ثلاث فئات: أولا التأثيرات المعرفية: وتشات اتشمل كثف الغموض، تكوين الاتجاهات، ترتيب

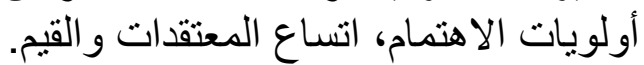
ثانيا التأثيرات الوجدانية: وتتضمن الفتور العاطفي، الخوف و القلق، الدعم

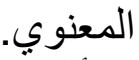
ثالثا التأثيرات السلوكية: تتحصر الأثار السلوكية في سلوكين اساسين:

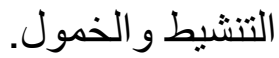
3.1 .3 أوجه الاستفادة من هذه النظرية في هذا فذا البحث

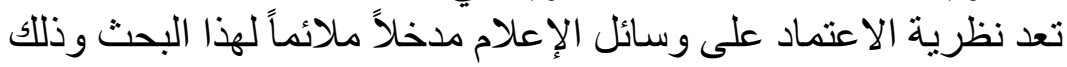
للأسباب الاتية: 1) تفترض النظرية زيادة اعتماد الجمهور على وسائل الإعلام لاستقاء

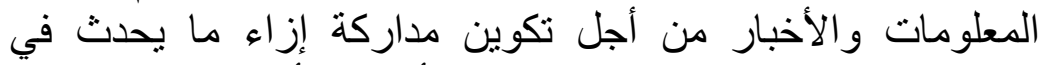

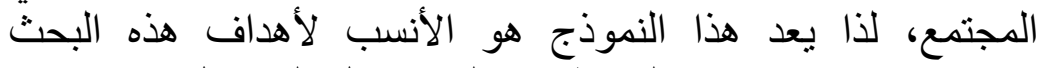

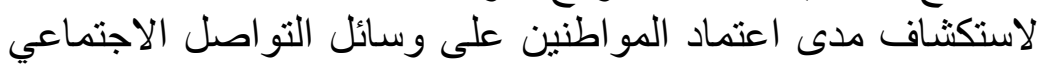
للتو عية بالمبادر ات الصنية اعنية. 2) تقيد في التعرف على مدى التأثير ات المنرتبة على اعتى اعتماد المواطنين

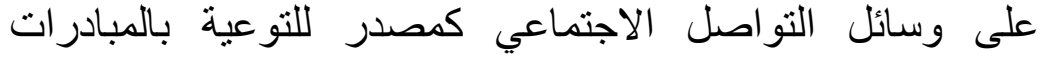


الصحية، وقد تكون تلك التأثثر ات معرفية أو وجدانية أو سلوكية، حيث

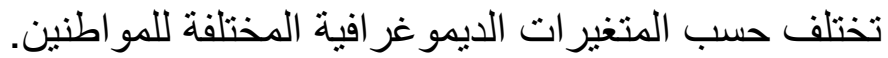
4 التعريفات الإجرائية للاربةاسة الإنة الإعلام الجديا: الإجرانية إعلام متعدد الأشكال (مسموعاً ومرئياً ومقروءاً)،

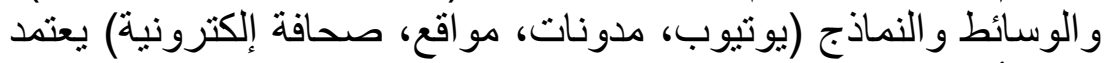

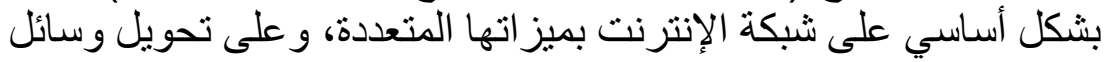

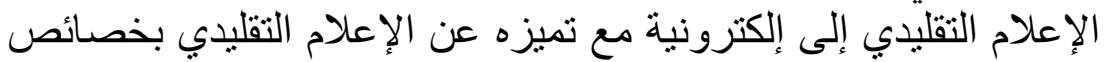

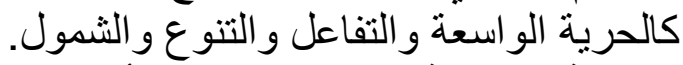

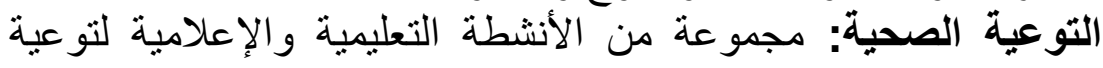

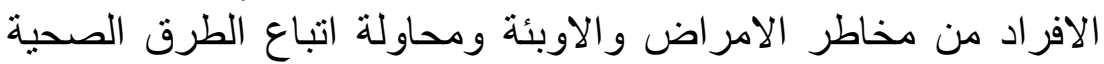

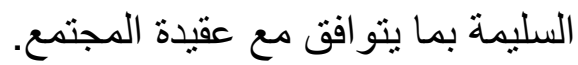

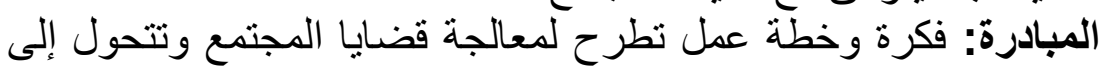

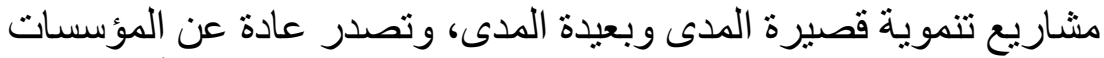

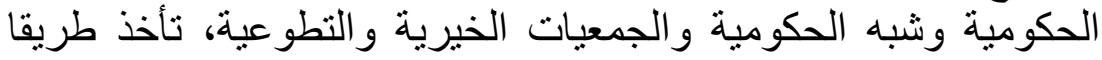

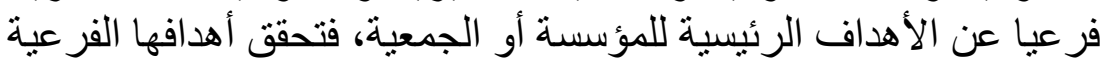

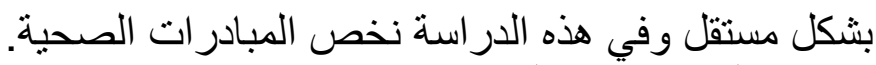
5

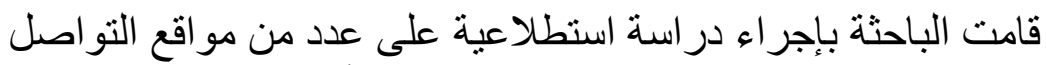

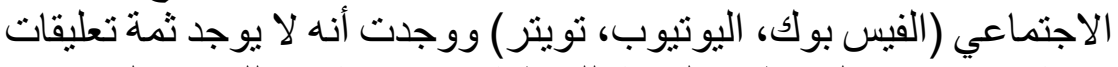

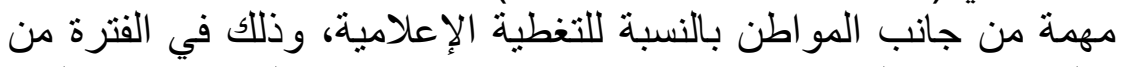

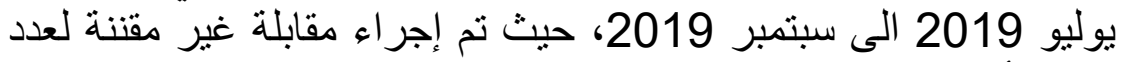

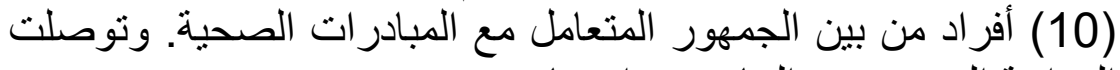

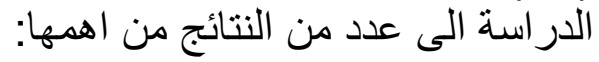

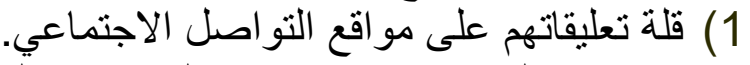

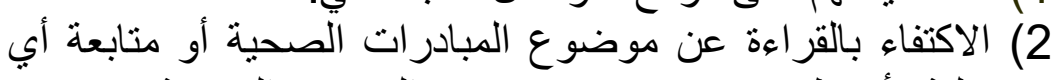

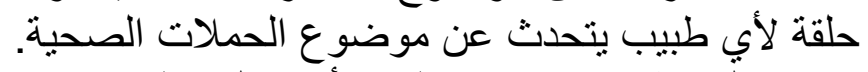

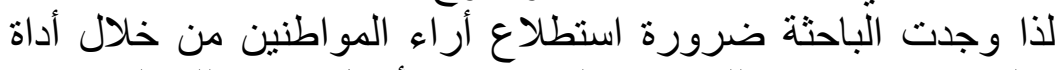

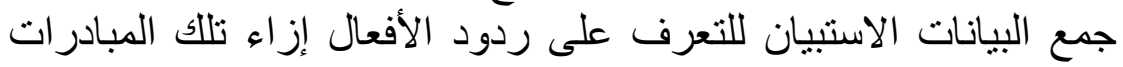

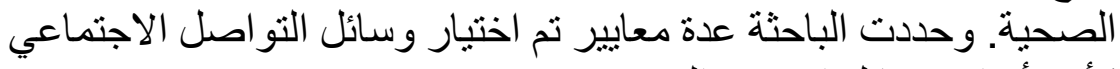

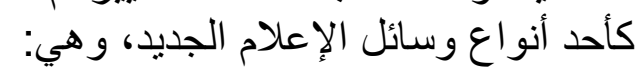

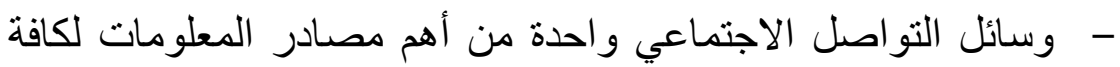

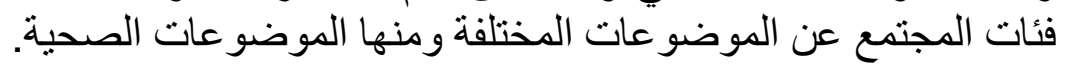

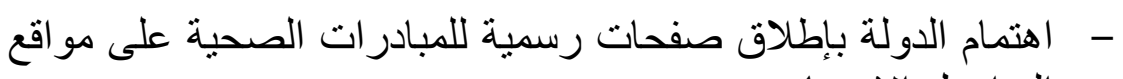

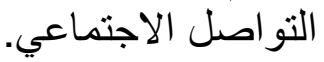




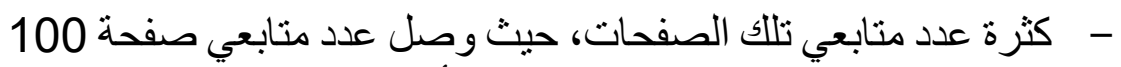
مليون صحة علّى موقع الفيس بوك إلى ألى أكثر من مليون متابع.

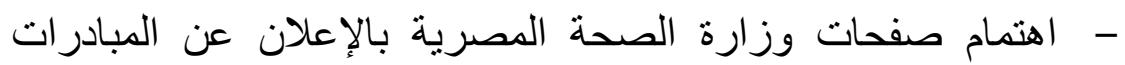

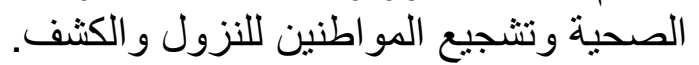
- التحديث المستمر لأخبار المبادرات الصحية على مواقع التواصن لاصن الاجتماعي. - - التفاعلية المتاحة على مواقع التواصل الاجتماعي وسرعة الرد على الرئ استفسار ات المو اطنين. 6 مشكلة الدراسة

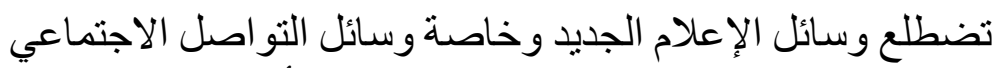

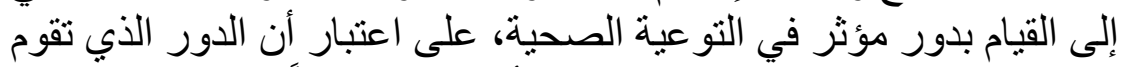

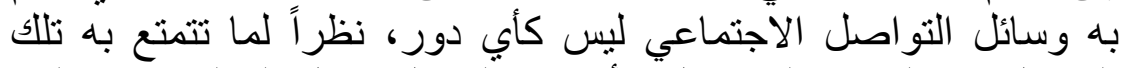

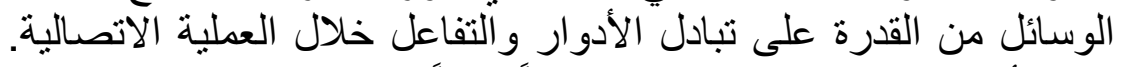

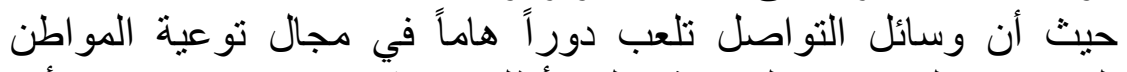

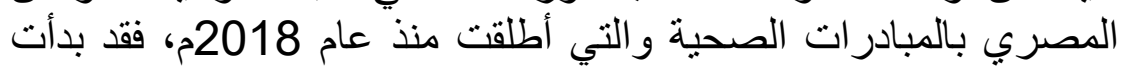

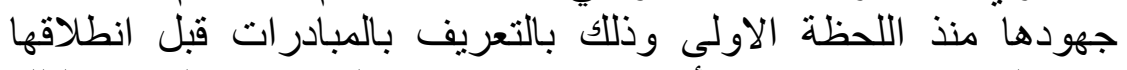

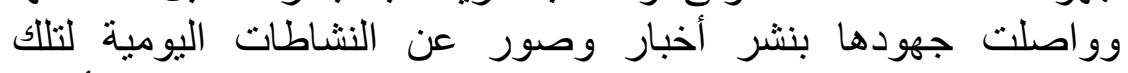

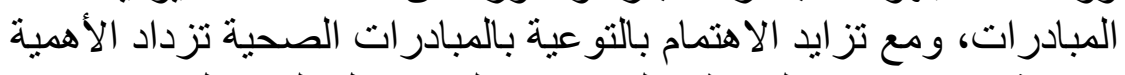

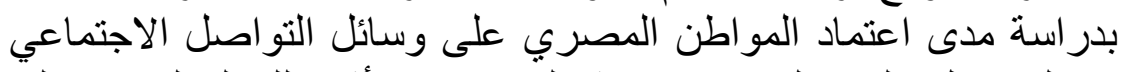

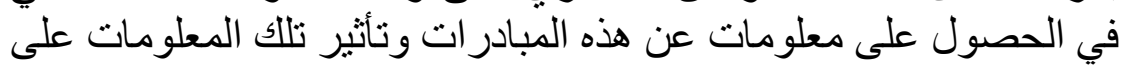

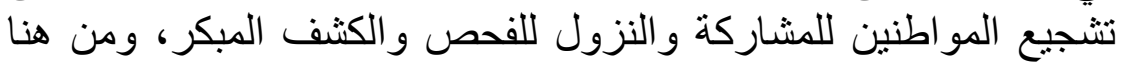

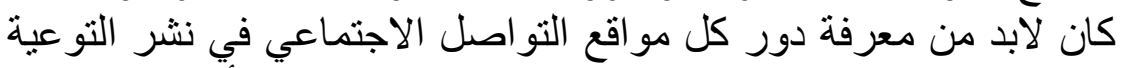

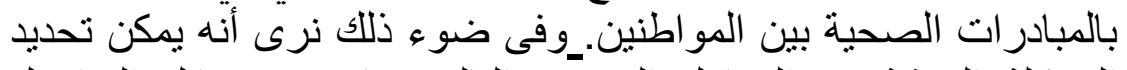

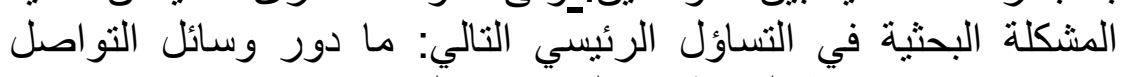

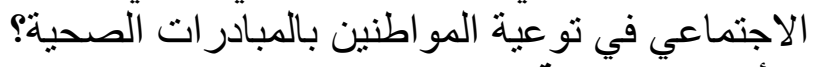

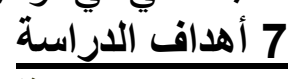

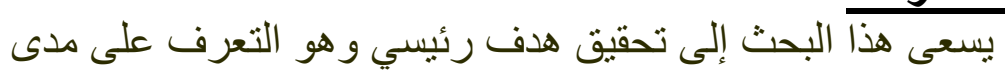

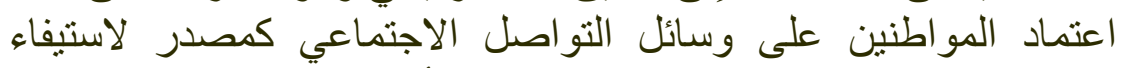

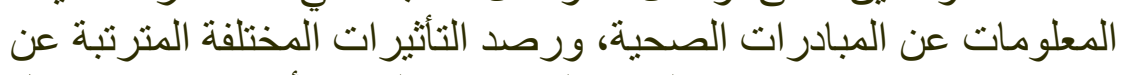

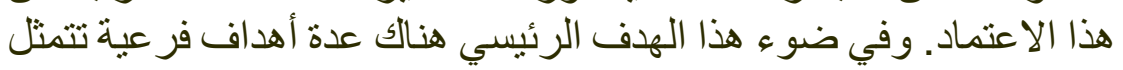

1) مدى اعتماد المو اطنين على وسائل التو اصل الاجتماعي.

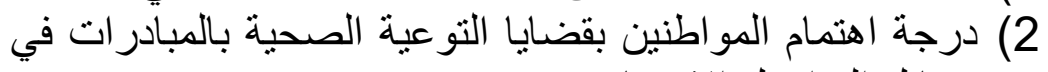
وسائل التو اصل التئل الاجتماعي. 


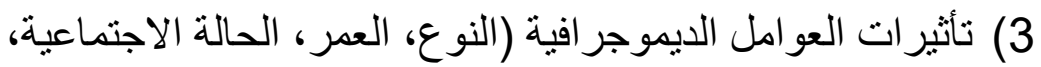

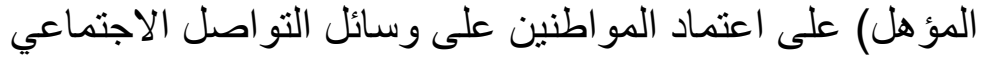
للتو عية بالمبادر ات الصحية.

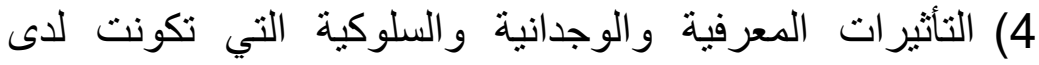

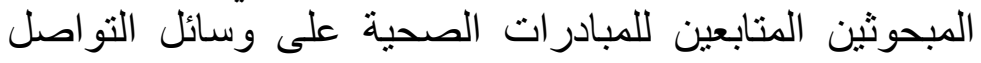

$$
\begin{aligned}
& \text { الاجتماعي. } \\
& 8 \text { فروض وتساؤلات الدراسة } \\
& 1.8 \text { تساؤلات الدراسة }
\end{aligned}
$$

1- ما معدل متابعة المواطنين للمبادرات الصحية في وسائل التواصل

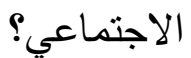

2- ما مدى اهتمام المو اطنين بمتابعة أخبار المبادر ات الصحية في وسائل

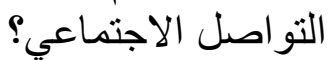
3- ما أهم المبادرات الصنهية التي ركزت عليها وسائل التواصل الاجتماعي؟ 4- ما مدى رضا المو اطنين عن قضايا التوعية الصحية بالمبادرات في

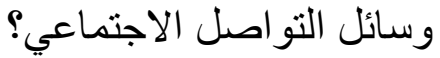
5- ما درجة ثقة المواطنين في قضايا التوعية الصحية بالمبادرات في وسائل التو اصل الاجتماعي؟

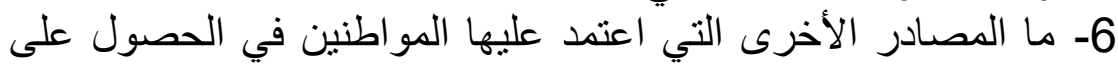

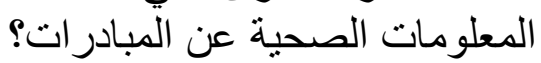
7- ما أهم التأثثرات المعرفية والوجدانية والسلوكية المتكونة لاى المى المو اطنين؟ 2.8 فروض الدراسة 1- الفرض الأول: - توجد فروق معنوية ذات دلاله إحصائية بين المو اطنين

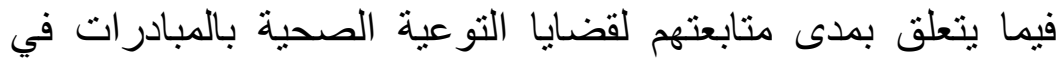

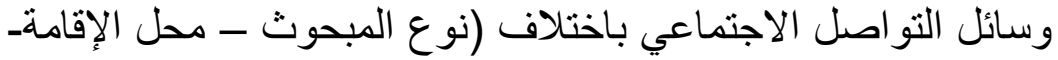

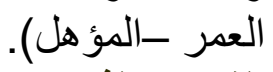

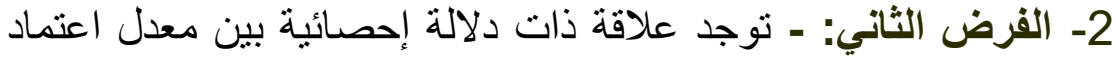

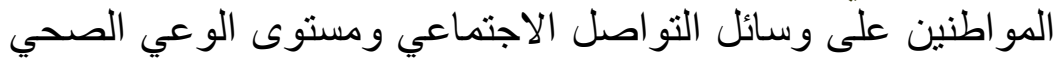

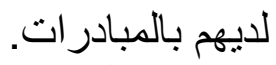
3- الفرض الثالث: - توجد علاقة ذات دلالة إحصائية بين معدل اعتماد

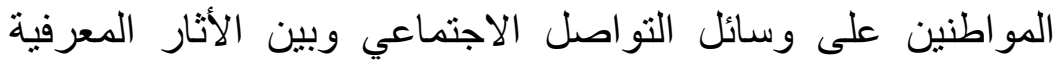
و السلوكية و الوجدانية المتكونة لدينه. 
4- الفرض الرابع: - توجد علاقات ارتباطية ذات دلالة إحصائية بين تقيبم

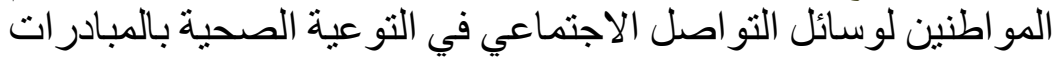
و وبين معدل اعتمادهم على تلك الكئل الوسائل. 9 نوع البحث العثر

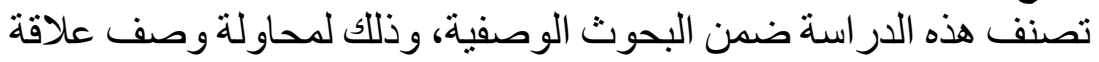

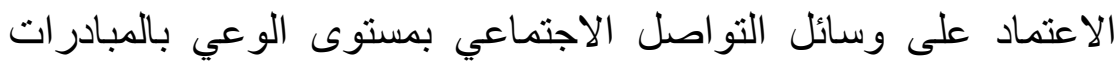
الصحية للى المو اطن المصري.

المنهج المستخدم (منهج المسح بالعينة) المسح بالعينة على عينة من المو اطنين من الثعب المن المصري.

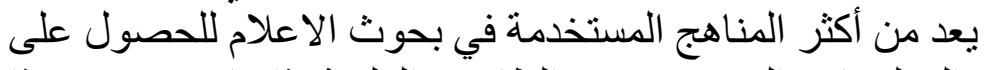

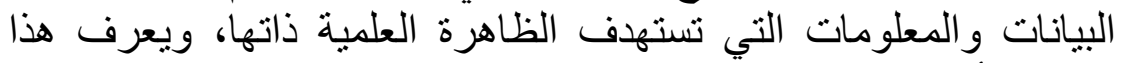

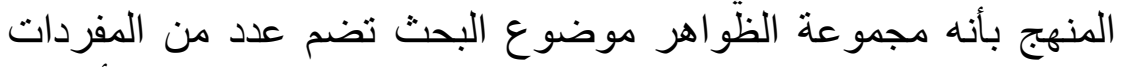

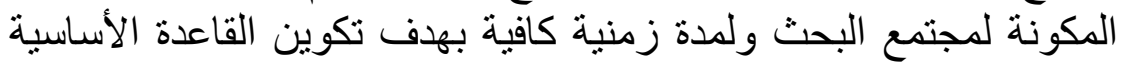

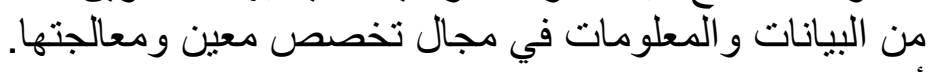

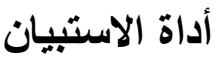

هو أداة جمع البيانات عن طريق استثارة الأفراد المبحوثين بطريقة منهجية للحصول منهم على أفكار وأر اء معينة في إطار البرات البيانات

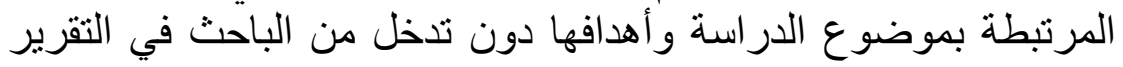

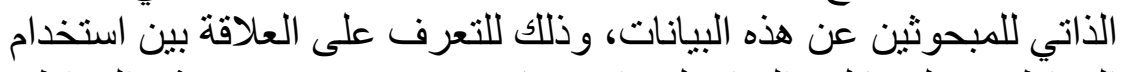

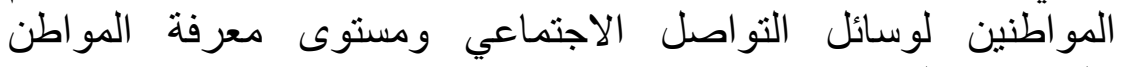
بالمبادر ات الصحية، وتتكون من ثلاثة محأور:

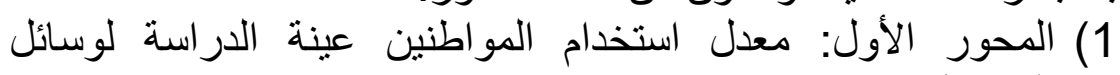

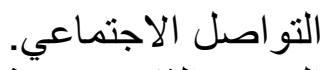

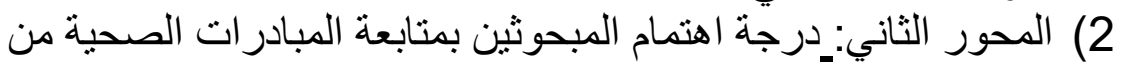

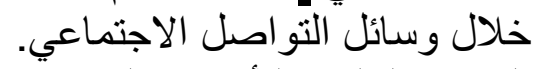
3) المحور الثالث: التأثير ات المعرفية والوجدانية والسلوكية المتكونة لدى

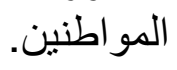

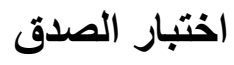

تم تطبيق اختبار الصدق للتأكد من الصدق الظاهري للاستمارة،

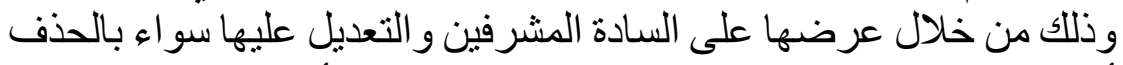

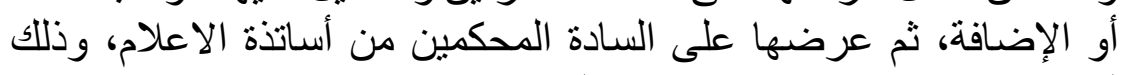

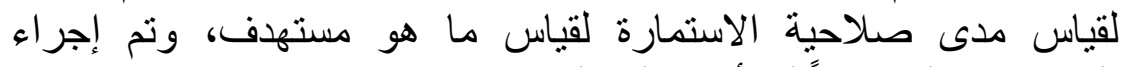
التعديلات عليها وفقاً لما أشثار إليه المحكمون. 
اختبار الثبات

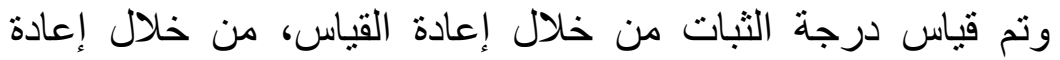

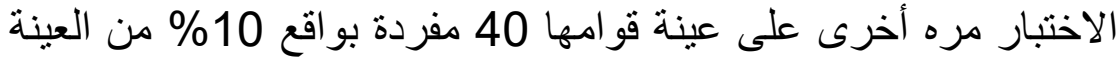

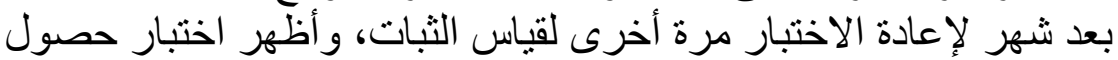

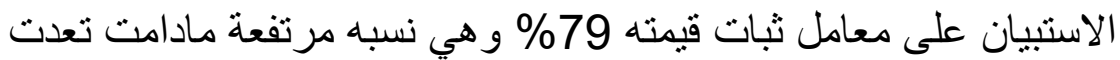

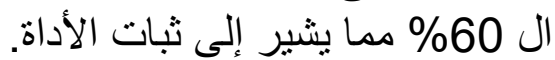
الجوانب الإجرائية

مجتمع البحث: والجرائة ويهتم البحث بدر اسة المواطنون من الثعب المصري.

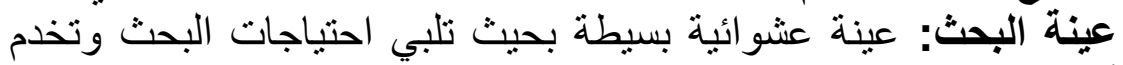

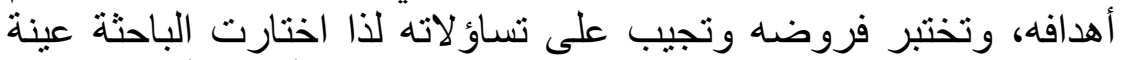

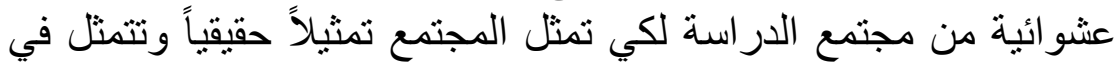

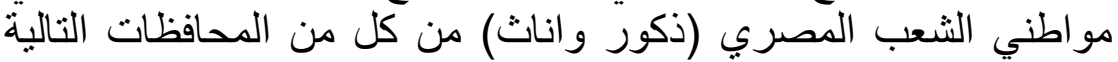
(دمياط، القاهرة، المنيا) وتتمثل العينة في 400 مفرده الإنه المعالجة الإحصائية للبياتات الاتيات

بعد الانتهاء من جمع بيانات الدراسة، نمانيات نم إدخالها -بعد نرميزها-

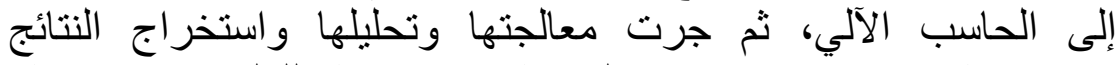
الإحصائية باستخدام برنامج "الحزمة الإحصائية للعلوم الاجتماعية"

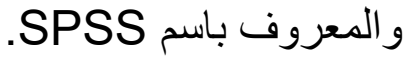
10 نتائج البحث

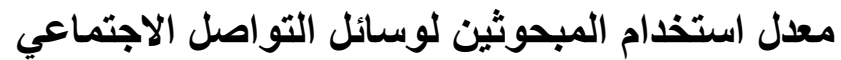

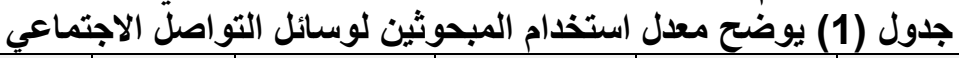

\begin{tabular}{|c|c|c|c|c|c|c|c|c|}
\hline \multirow{2}{*}{ المعياري } & \multirow{2}{*}{ حتوسط } & \multicolumn{2}{|c|}{ دائماً } & \multicolumn{2}{|c|}{ أحياناً } & \multicolumn{2}{|c|}{$y$} & \multirow{2}{*}{ الوسائل } \\
\hline & & $\%$ & ك & $\%$ & ك & $\%$ & ك & \\
\hline 0.387 & 2.86 & 87.2 & 319 & 11.5 & 42 & 1.4 & 5 & الفيس بوك \\
\hline 0.613 & 2.39 & 45.9 & 168 & 47.3 & 173 & 6.8 & 25 & يوتيوب \\
\hline 0.785 & 1.99 & 30.1 & 110 & 38.5 & 141 & 31.4 & 115 & انستجر ام \\
\hline 0.789 & 1.72 & 21 & 77 & 30.3 & 111 & 48.6 & 178 & جلاس \\
\hline 0.661 & 1.51 & 9.3 & 34 & 32.5 & 119 & 58.2 & 213 & تويتر \\
\hline 0.426 & 1.16 & 2.5 & 9 & 10.7 & 39 & 86.9 & 318 & هلوس \\
\hline 0.404 & 1.16 & 1.4 & 5 & 13.4 & 49 & 85.2 & 312 & ماي سبيس \\
\hline & & & & 366 & & & & الإجمالي \\
\hline
\end{tabular}




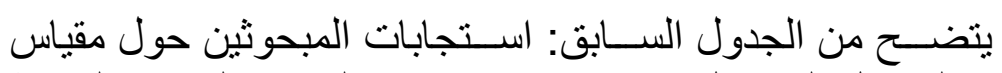

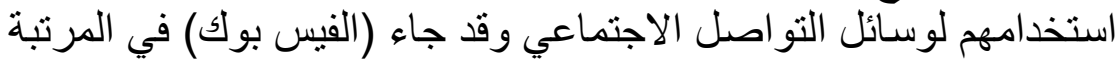

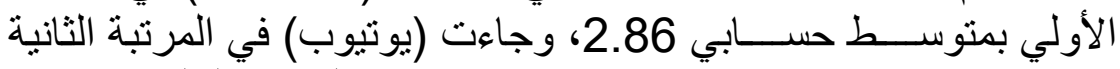

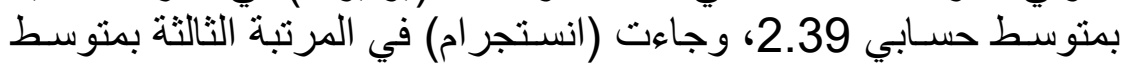

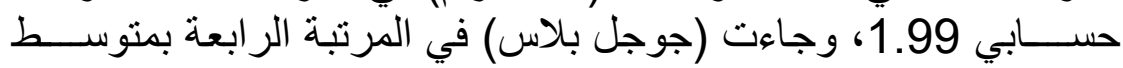

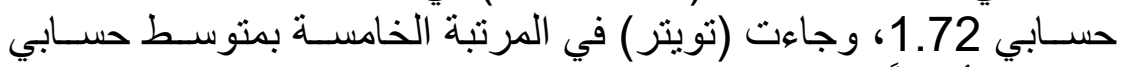

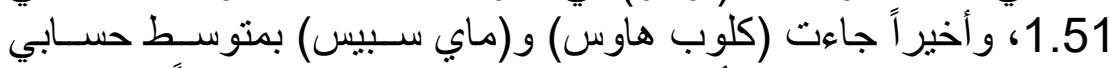

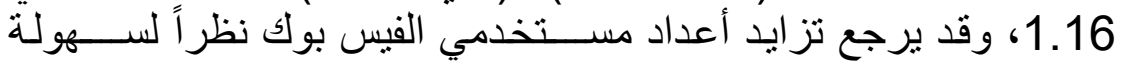

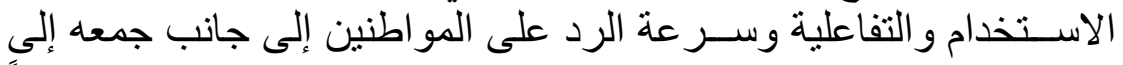

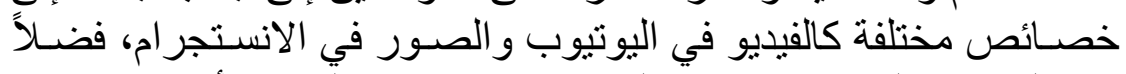

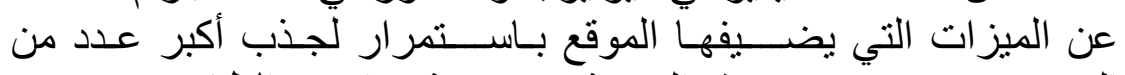

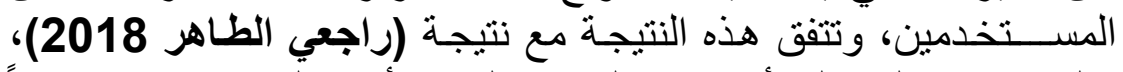

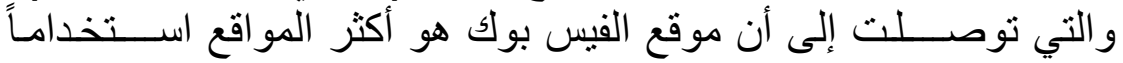

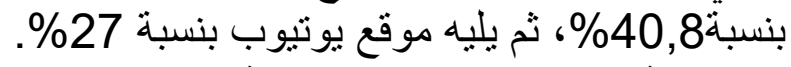

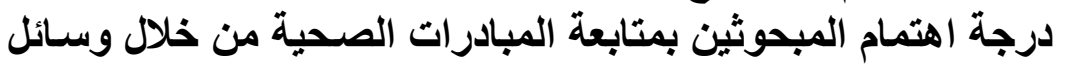
التواصل الاجتماعي جدول رقم (2) يوضح درجية الاجتمام المبحوثين بمتابعة المبادرات الصحية من خلال

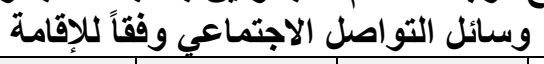

\begin{tabular}{|c|c|c|c|c|c|c|c|c|}
\hline \multicolumn{2}{|c|}{ الإجمالي } & \multicolumn{2}{|c|}{ المنيا } & \multicolumn{2}{|c|}{ دمياط } & \multicolumn{2}{|c|}{ الكبرى } & \multirow[t]{2}{*}{ / الاهتمام/ مكان الاقامة } \\
\hline$\%$ & ك & $\%$ & ك & $\%$ & ك & $\%$ & ك & \\
\hline 64.5 & 185 & 63.8 & 51 & 64.1 & 75 & 65.6 & 59 & مهتم الى حد ما \\
\hline 28.2 & 81 & 32.5 & 26 & 24.8 & 29 & 28.9 & 26 & مهتم جدا \\
\hline 7.3 & 21 & 3.8 & 3 & 11.1 & 13 & 5.6 & 5 & غير مهتم \\
\hline 100 & 287 & 100 & 80 & 100 & 117 & 100 & 90 & الإجمالي \\
\hline
\end{tabular}

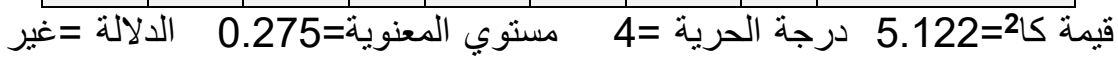
دالة معامل التو افق=0.132

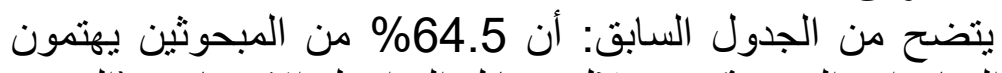

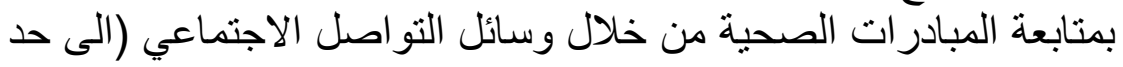

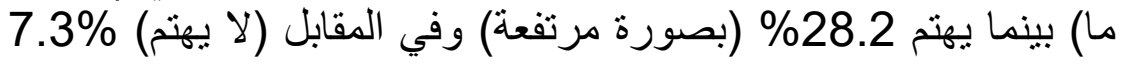


وتثنير النتائج إلى اهتمام عينة الدر اسة بمتابعة المبادر ات الصحية

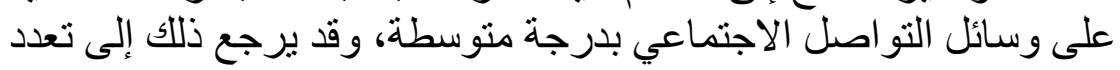

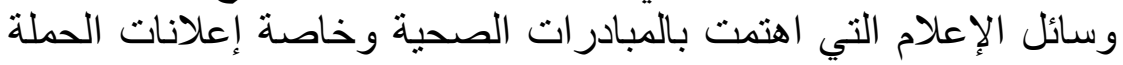

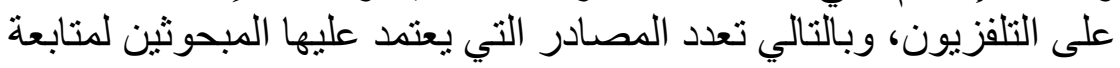

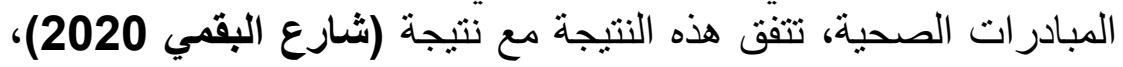

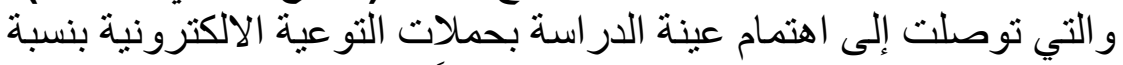

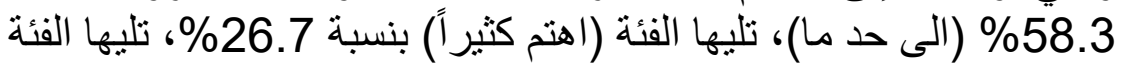

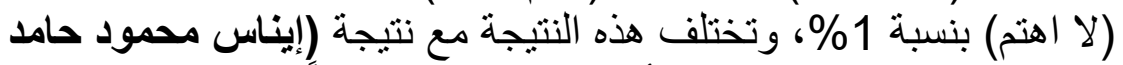

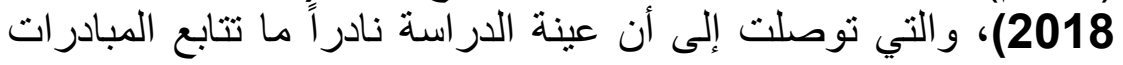

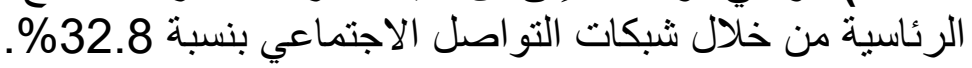

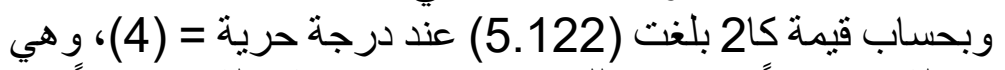

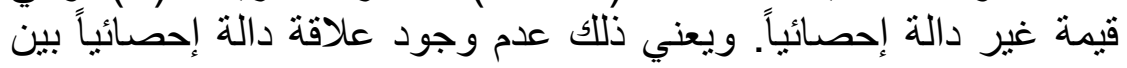

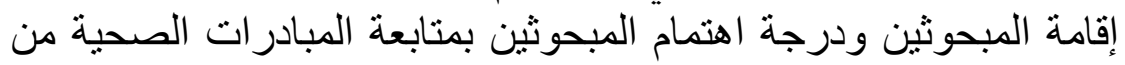

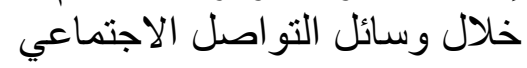

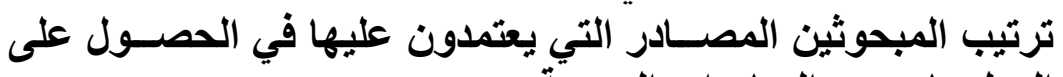
المعلومات عن المبادرات المبن المديّية جدول (3) يوضح ترتيب المبحوثين المصادر التي يعتمدون عليها في الحصول على الصى المعلومات عن المبادرات الصحية الصئية

\begin{tabular}{|c|c|c|c|c|c|c|c|}
\hline \multicolumn{2}{|c|}{ الوزن المرجح } & \multirow{2}{*}{ الخامس } & \multirow{2}{*}{ الرابع } & \multirow{2}{*}{ الثالث } & \multirow{2}{*}{ الثاني } & \multirow{2}{*}{ الأول } & \multirow[t]{2}{*}{ الترتيب } \\
\hline مئوي & النقاط & & & & & & \\
\hline 23.4 & 1006 & 37 & 44 & 50 & 49 & 107 & الاجتماعى $\quad$ التو اصل \\
\hline 20.8 & 896 & 36 & 61 & 66 & 80 & 44 & الالكترونع $\quad$ الإخبارية \\
\hline 20.3 & 872 & 48 & 46 & 84 & 65 & 44 & الصحية $\quad$ الالكترونية \\
\hline 19.1 & 820 & 59 & 83 & 43 & 44 & 58 & 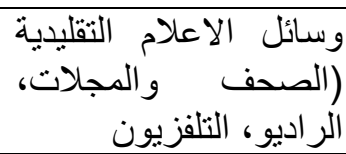 \\
\hline 16.5 & 711 & 107 & 53 & 44 & 49 & 34 & المحيطون بي \\
\hline \multicolumn{2}{|c|}{4305} & \multicolumn{6}{|c|}{ مجموع الأوزان المرجحة ن= 287} \\
\hline
\end{tabular}


يتضح من الجدول السابق: أن نرثيب المبحوثين المصادر التي

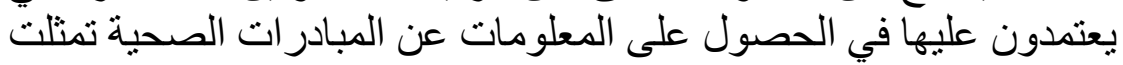

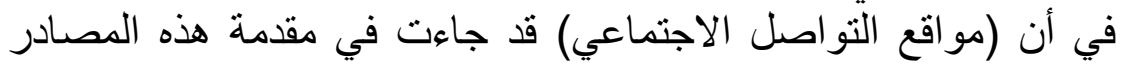

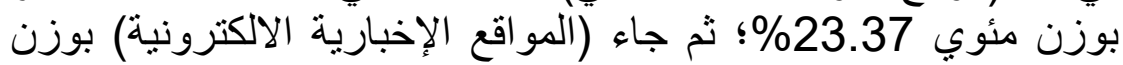

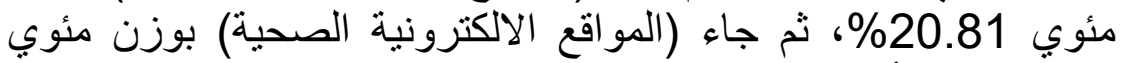

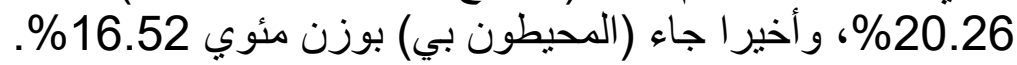

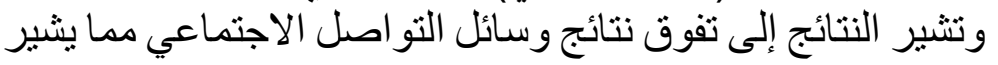

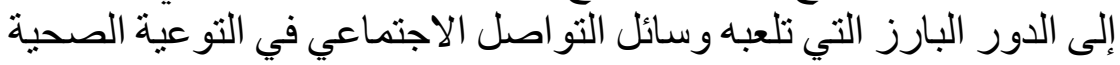

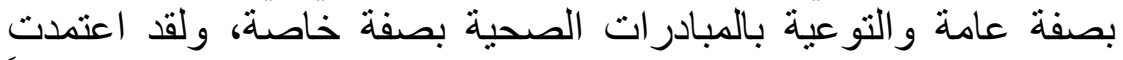

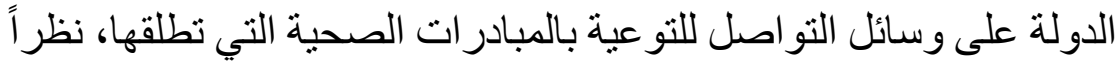

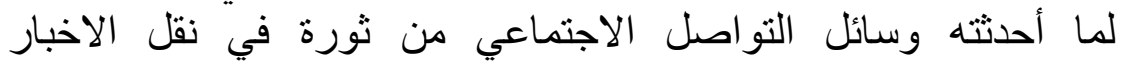

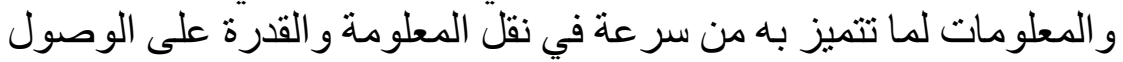

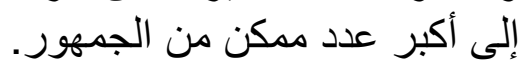

كما تتفق هذه النتيجة مع نتيجة التئة (إيناس محمود حامد 2018)،

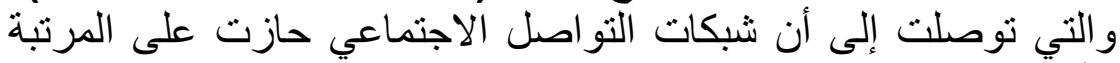

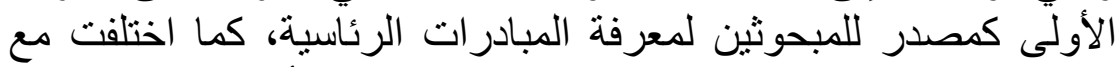

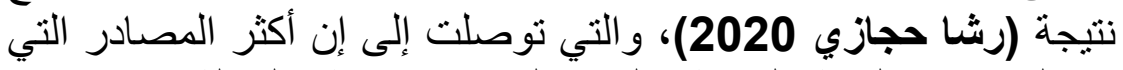

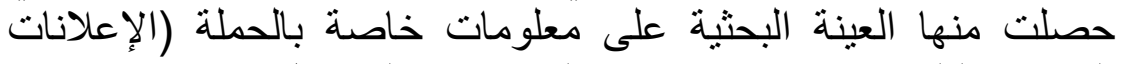
المذاعة بالتلفزيون) بنسبة 78\%، تلتها مو اقع التو اصل الاجتماعي بندة بنسبة $\% 60$ • ملات التوعية الصـــية التي تابعها المبحوثين من خلال وســائل التواصل الاجتماعي 
جدول رقم (4) يوضح حملات التوعية الصحية التي تابعها المبحوثين من خلال وسائل التواصل الاجتماعي وفقاً للإقامة

\begin{tabular}{|c|c|c|c|c|c|c|c|c|c|c|}
\hline \multirow{2}{*}{ 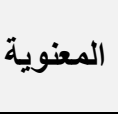 } & \multirow{2}{*}{25} & \multicolumn{2}{|c|}{ الإجمالي } & \multicolumn{2}{|c|}{ 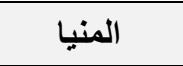 } & \multicolumn{2}{|c|}{ 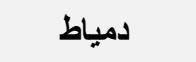 } & \multicolumn{2}{|c|}{ القاهرة الكبرى } & \multirow{2}{*}{ الحملات } \\
\hline & & $\%$ & ك5 & $\%$ & ك5 & $\%$ & ك & $\%$ & ك5 & \\
\hline 0.652 & 0.855 & 83.3 & 239 & 80 & 64 & 84.6 & 99 & 84.4 & 76 & مبادرة 100 مليون صحة \\
\hline 0.33 & 2.215 & 53.3 & 153 & 47.5 & 38 & 58.1 & 68 & 52.2 & 47 & حملات التطعيم ضد شلل الأطفال \\
\hline 0.013 & 8.749 & 47.7 & 137 & 33.8 & 27 & 53.8 & 63 & 52.2 & 47 & مبادرة صحة المر أة المصرية \\
\hline 0.682 & 0.765 & 31.4 & 90 & 28.8 & 23 & 34.2 & 40 & 30 & 27 & مبادرة التأمين الصحي الشـامل \\
\hline 0.733 & 0.621 & 30.3 & 87 & 33.8 & 27 & 29.1 & 34 & 28.9 & 26 & حياة كريمة \\
\hline 0.405 & 1.808 & 28.2 & 81 & 22.5 & 18 & 30.8 & 36 & 30 & 27 & حملات التطعيم الدورية للأطفال الرضع \\
\hline 0.266 & 2.649 & 17.4 & 50 & 12.5 & 10 & 21.4 & 25 & 16.7 & 15 & مبادرة القضاء على الامر اض المزمنة \\
\hline 0.441 & 1.639 & 17.1 & 49 & 12.5 & 10 & 18.8 & 22 & 18.9 & 17 & الكثف عن التقزم و السمنة و الانيميا \\
\hline 0.761 & 0.545 & 13.6 & 39 & 12.5 & 10 & 15.4 & 18 & 12.2 & 11 & صحتنا في أسلوب حياة \\
\hline 0.078 & 5.095 & 13.6 & 39 & 6.3 & 5 & 16.2 & 19 & 16.7 & 15 & الجدادرة الكثف عن ضعاف السمع بين المواليد \\
\hline 0.125 & 4.155 & 10.5 & 30 & 10 & 8 & 6.8 & 8 & 15.6 & 14 & مبادرة نور حياة \\
\hline 0.139 & 3.942 & 8.7 & 25 & 3.8 & 3 & 9.4 & 11 & 12.2 & 11 & مبادرة القضاء على قو ائم الانتظار \\
\hline 0.358 & 2.053 & 2.8 & 8 & 5 & 4 & 1.7 & 2 & 2.2 & 2 & حضانات للأطفال المبتسرين \\
\hline & & 100 & 287 & 100 & 80 & 100 & 117 & 100 & 90 & جملة من سئلوا \\
\hline
\end{tabular}


يتضح من الجدول السابق: جاء (مبادرة 100 مليون صحة) في

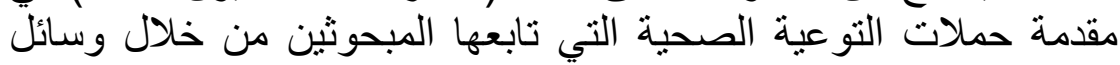

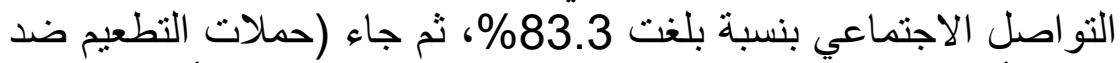

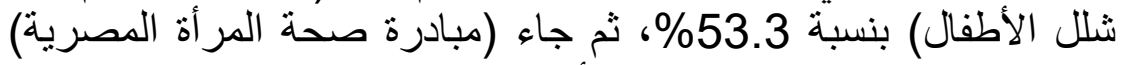

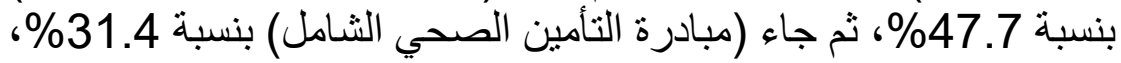

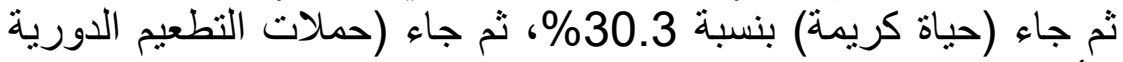

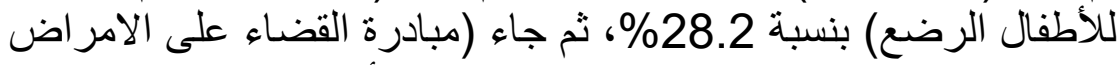
المزمنة) بنسبة 17.4\%، ثم جاء (حضانات للأطفال المبنسرين) بنسبة \%2.8

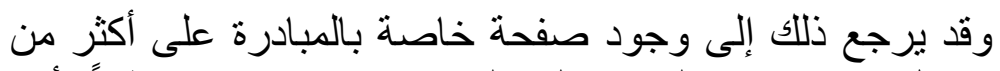

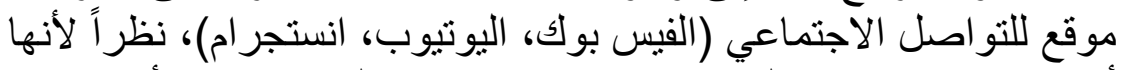

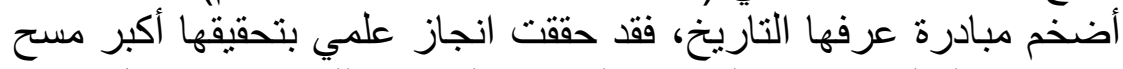

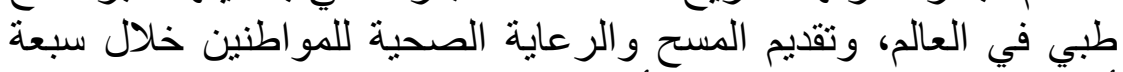

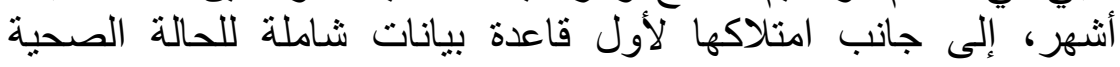
للمواطنين. اتفقت هذه النتيجة مع نتيجة (السيد السعيد عبد الوكاب الوهاب

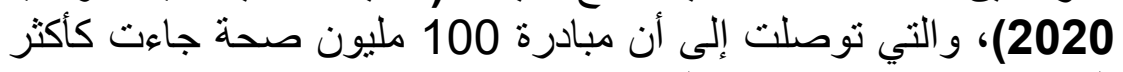

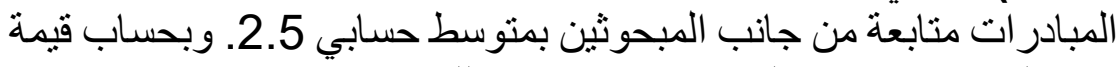

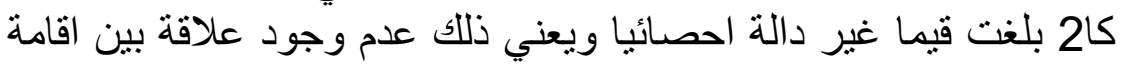

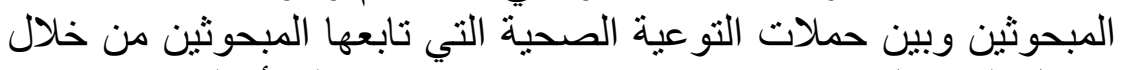

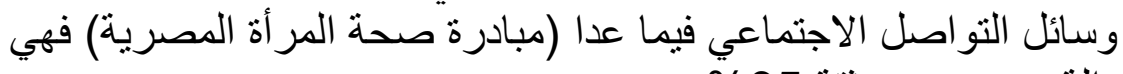

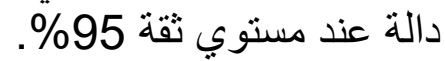
مدي اسـهام وسـائل التواصلة ولهل الاجتماعي في نشر الوعي بالمبادرات

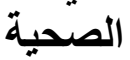
جدول رقم (5) يوضح مدي اسهام وسائل التواصل الاجتماعي في نشر الوعي بالمبادرات الصحية وفقاً للإقامة الاجتياء

\begin{tabular}{|c|c|c|c|c|c|c|c|c|}
\hline \multicolumn{2}{|c|}{ الإجمالي } & \multicolumn{2}{|c|}{ المنيا } & \multicolumn{2}{|c|}{ دمياط } & \multicolumn{2}{|c|}{ القاهرة الكبرى } & \multirow[t]{2}{*}{ مدى/ الاقامة } \\
\hline$\%$ & كs & $\%$ & ك5 & $\%$ & ك & $\%$ & ك5 & \\
\hline 42 & 120 & 38 & 30 & 43 & 50 & 44.4 & 40 & دائما \\
\hline 54 & 155 & 56 & 45 & 55 & 64 & 51.1 & 46 & أحيانا \\
\hline 4.2 & 12 & 6.3 & 5 & 2.6 & 3 & 4.4 & 4 & $y$ \\
\hline 100 & 287 & 100 & 80 & 100 & 117 & 100 & 90 & الإجمالي \\
\hline
\end{tabular}




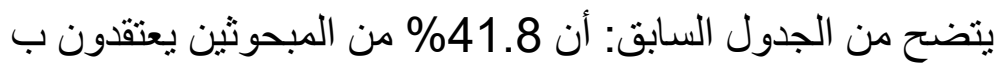

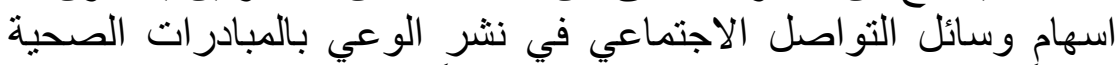

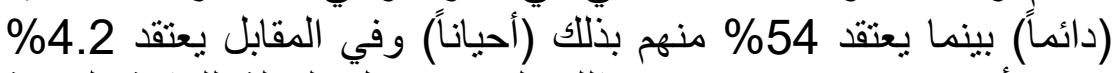

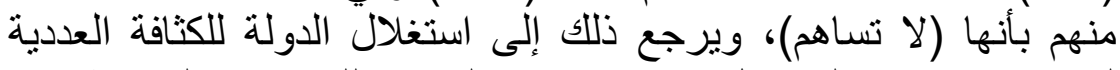

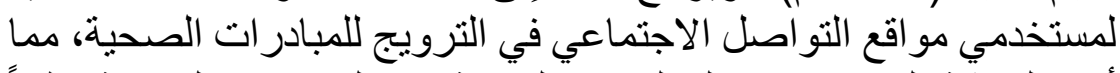

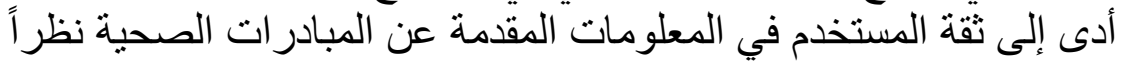

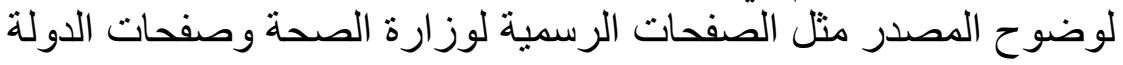
المعنية بالمجال الصحي. وبحساب قيمة كُا2 بلغت (2.319) عند درجة حرية = (4) (4)، وهي

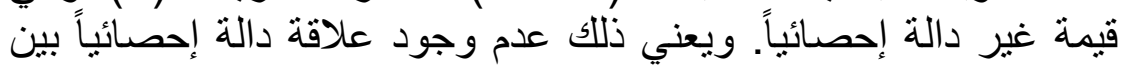

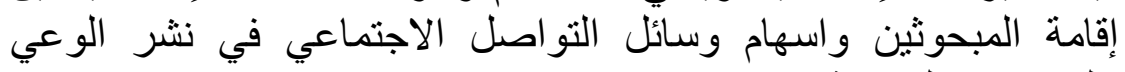
بالمبادر ات الصحية. • طرق تجاوب المبحوثين مع المبادرات الصحية على مواقع التواصل الاجتماعي 
جدول (6) يوضح طرق تجاوب المبحوثين مع المبادرات الصحية على مواقع التواصل الاجتماعي

\begin{tabular}{|c|c|c|c|c|c|c|c|c|}
\hline \multirow{2}{*}{ 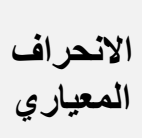 } & \multirow{2}{*}{ الحستابي } & \multicolumn{2}{|c|}{ دائماً } & \multicolumn{2}{|c|}{ أحياناً } & \multicolumn{2}{|c|}{ ע } & \multirow[b]{2}{*}{ 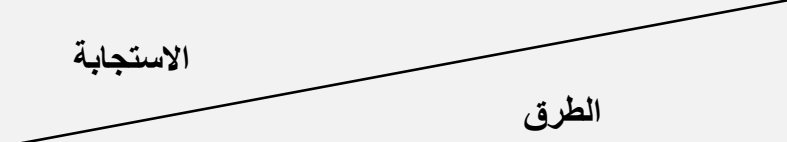 } \\
\hline & & $\%$ & ك & $\%$ & ك & $\%$ & ك & \\
\hline 0.652 & 2.36 & 45.3 & 130 & 44.9 & 129 & 9.8 & 28 & أسجل اعجابي بالمحتوى الخاص بالمبادرات الصحية \\
\hline 0.621 & 2.36 & 43.9 & 126 & 48.4 & 139 & 7.7 & 22 & اقرأ التعليقات التي يطرحها القراء على المبادرات الصحية \\
\hline 0.604 & 2.32 & 39.4 & 113 & 53.3 & 153 & 7.3 & 21 & التبحية الر أي مع زملائي و اسرتي ومعارفي عن المبادرات \\
\hline 0.65 & 2.13 & 28.6 & 82 & 56.1 & 161 & 15.3 & 44 & الببادر عن مصادر إعلامية أخرى للمزيد من التفاصيل حول \\
\hline 0.701 & 2.03 & 26.1 & 75 & 50.9 & 146 & 23 & 66 & الاجتماعي بمشاركة المحتوى مع أصدقائي على مواقع التواصل \\
\hline 0.722 & 1.94 & 23.3 & 67 & 47.7 & 137 & 28.9 & 83 & أنشارك بالتعليق على المحتوى الخاص المبادر ات الصحية \\
\hline 0.667 & 1.9 & 17.8 & 51 & 54.7 & 157 & 27.5 & 79 & اتصفحه فقط \\
\hline \multirow[t]{2}{*}{0.647} & 1.67 & 9.8 & 28 & 47.4 & 136 & 42.9 & 123 & لا أقوم بشيء أو فعل محدد \\
\hline & & \multicolumn{6}{|c|}{287} & الإجمالي \\
\hline
\end{tabular}


كما يتضح من الجدول السابق: استجابات المبحوثين حول مقياس

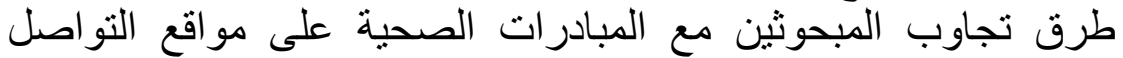

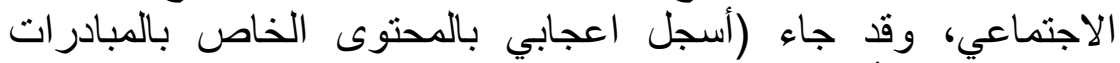

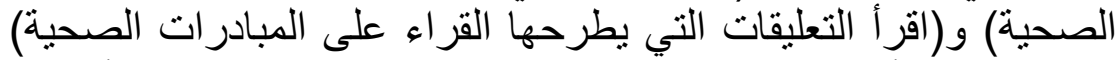

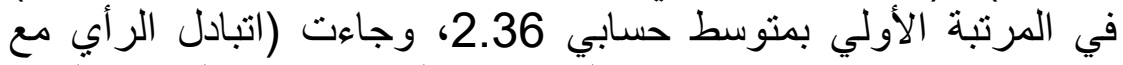

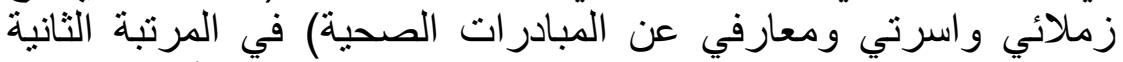

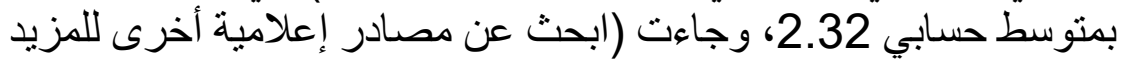

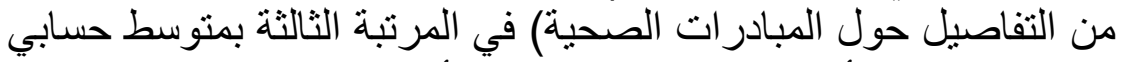

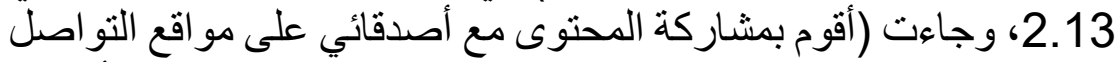

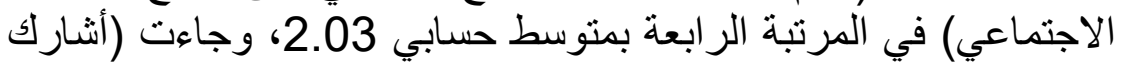

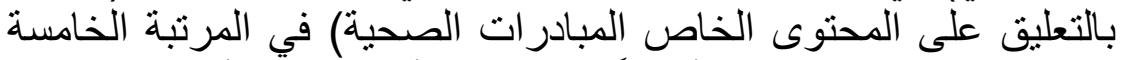
بمنوسط حسابي 1.94، وأخيراً جاءت (لا أقوم بشيء أو أو فعل محدد) بمتوسط حسابي 1.67. وقد ترجع هذه النتيجة إلى سببين: اما استعجال متصفح وسائل

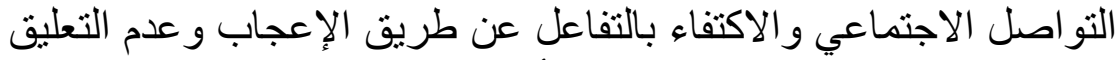

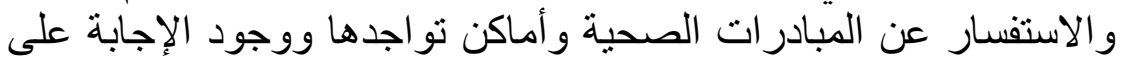

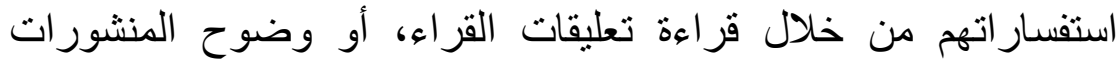
المتعلقة بالمبادرات الصحية وبالتالي لن يكون المتصفح بحات بحاجة للتعليق

وتتفق هذه النتيجة مع نتيجة (لبني قاسمي 2015)، و التي توصلت

و الاستفسار .

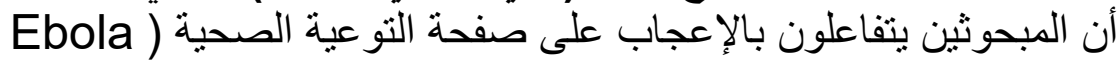

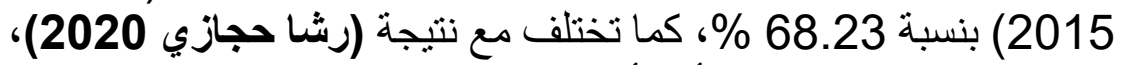

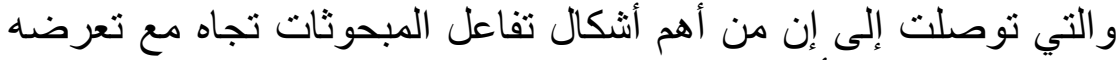

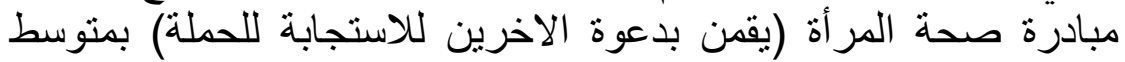

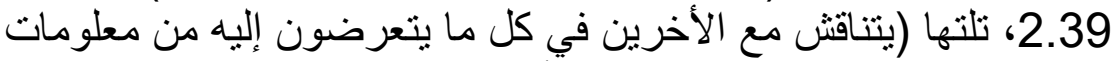

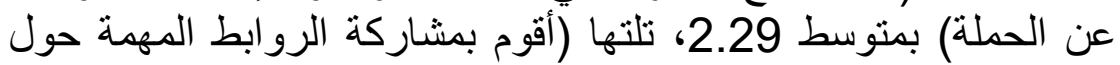

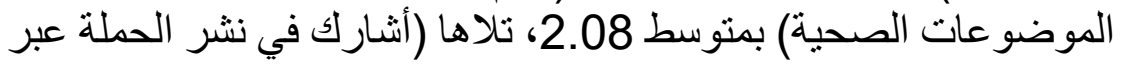

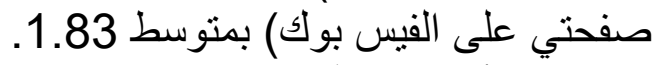
مدى تأثير متابعة المبحوثين للمبادرات الصحية عبر وسائل التواصل

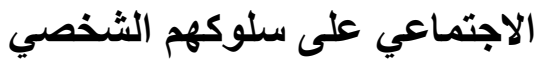


جدول (7) يوضح مدى تأثير متابعة المبحوثين للمبادرات الصحية عبر وسائل

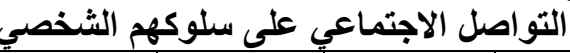

\begin{tabular}{|c|c|c|c|c|c|c|c|c|}
\hline \multirow{2}{*}{ المعياري } & \multirow{2}{*}{ المستوسط } & \multicolumn{2}{|c|}{ دائماً } & \multicolumn{2}{|c|}{ أحياناً } & \multicolumn{2}{|c|}{$y$} & \multirow{2}{*}{ التأثير الاستجابة } \\
\hline & & $\%$ & ك5 & $\%$ & ك5 & $\%$ & ك & \\
\hline 0.522 & 2.58 & 60 & 171 & 39 & 112 & 1.4 & 4 & تالتعل اصل مستخدمي وسائل \\
\hline 0.596 & 2.5 & 55 & 159 & 39 & 113 & 5.2 & 15 & المنعتني بضرورة اللتعرف \\
\hline 0.566 & 2.48 & 52 & 149 & 45 & 128 & 3.5 & 10 & تزوضيدي بطرق الوقاية من \\
\hline 0.588 & 2.44 & 49 & 141 & 46 & 132 & 4.9 & 14 & ساهمت في زيادة الوعي \\
\hline 0.58 & 2.43 & 47 & 135 & 48 & 139 & 4.5 & 13 & تزرق الّعلاج بمعلومات عن \\
\hline 0.616 & 2.3 & 39 & 111 & 53 & 152 & 8.4 & 24 & 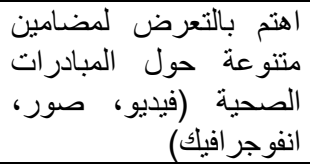 \\
\hline 0.56 & 2.51 & 54 & 155 & 43 & 123 & 3.1 & 9 & الإصاذة الحذر و الحيطة من مال \\
\hline 0.581 & 2.39 & 44 & 127 & 51 & 146 & 4.9 & 14 & لدى صنحتي الإحساس بالمسؤولية \\
\hline 0.661 & 2.32 & 43 & 124 & 46 & 132 & 11 & 31 & المواطن باهتمام الدولة بصحة \\
\hline 0.633 & 2.11 & 26 & 75 & 59 & 169 & 15 & 43 & الإصعابة بمرض مالة الخوف من \\
\hline 0.562 & 2.34 & 38 & 110 & 57 & 164 & 4.5 & 13 & 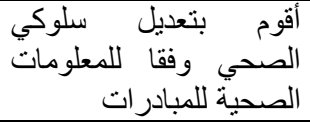 \\
\hline 0.606 & 2.24 & 33 & 96 & 58 & 165 & 9.1 & 26 & الصحية \\
\hline 0.678 & 2.21 & 36 & 102 & 50 & 143 & 15 & 42 & 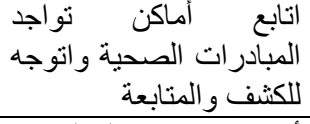 \\
\hline 0.658 & 1.99 & 21 & 61 & 57 & 163 & 22 & 63 & 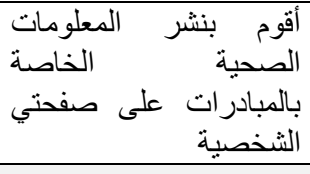 \\
\hline & & & 287 & & & & & الإجمالي \\
\hline
\end{tabular}




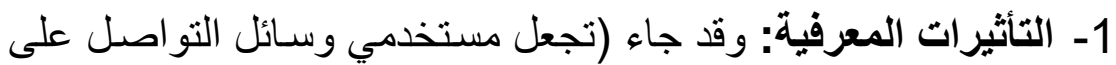

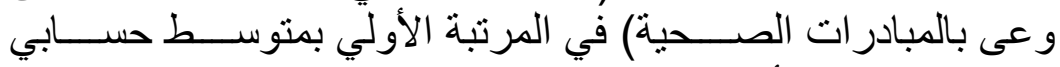

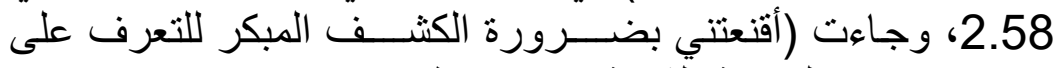

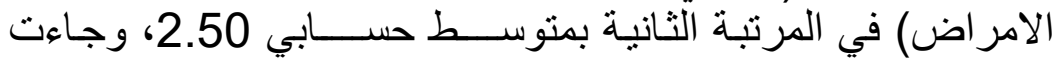

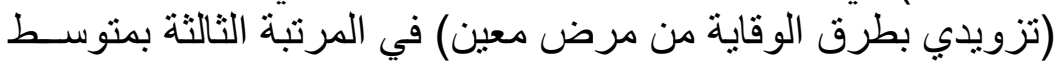

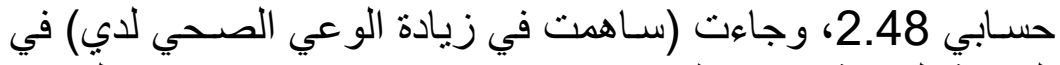

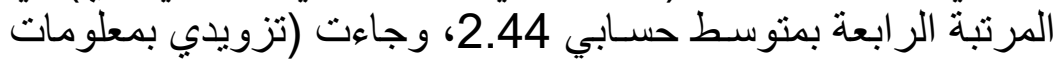

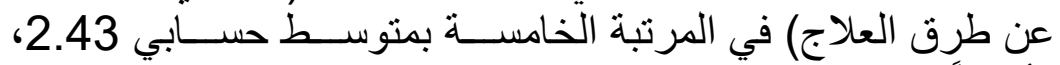

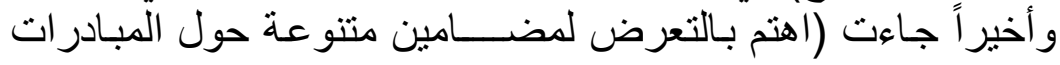

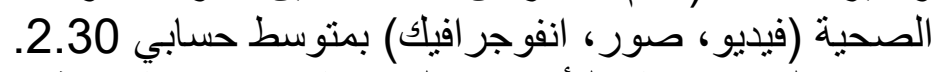

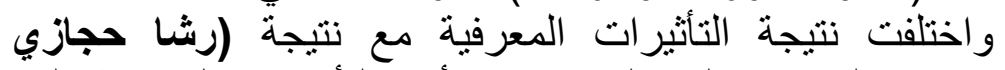

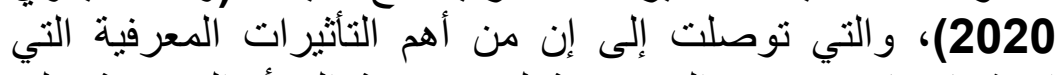

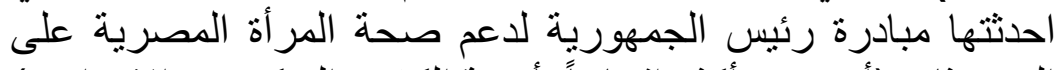

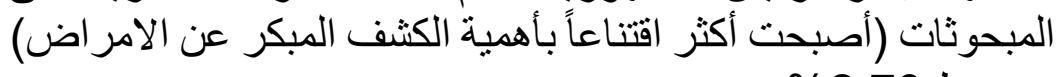
بمتوسط 2.70\%. 2- التأثيرات الوجدانية: وقد جاء (اتخاذ الحذر و الحيطة من الإصـــــابة

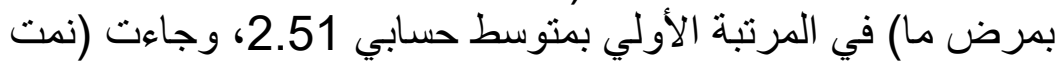

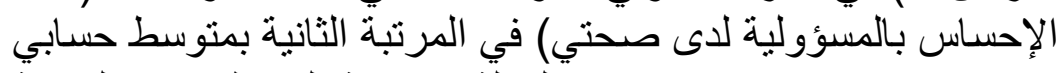

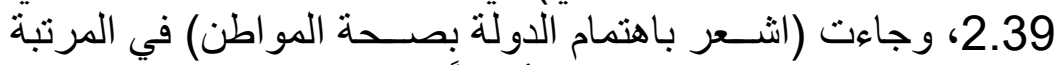

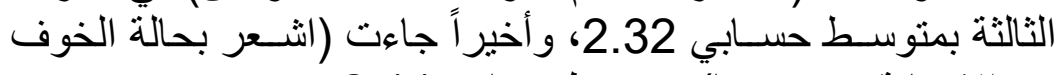

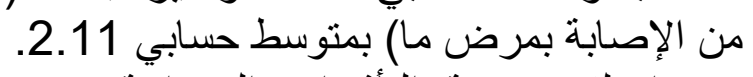

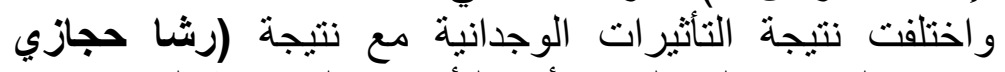
2020)، والتي توصلت إلى إن أهم التأثنيرات التهد الوجدانية التي احدثنها

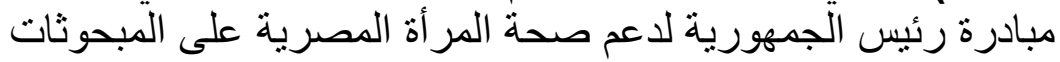

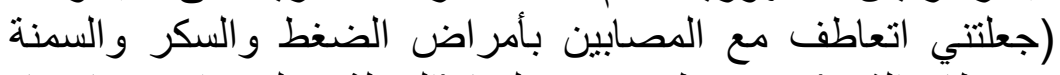

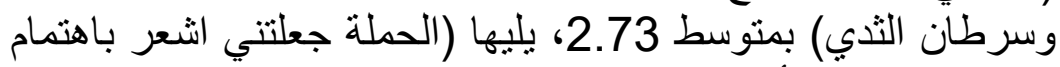

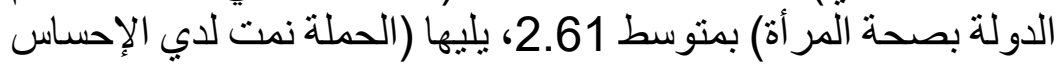

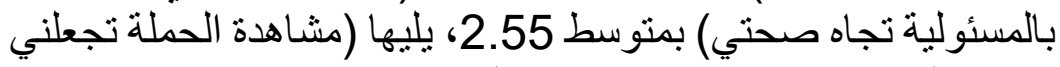

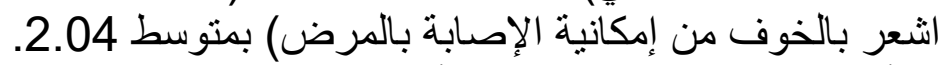

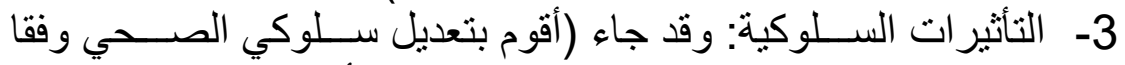

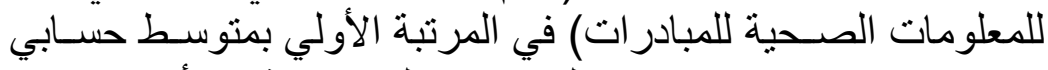

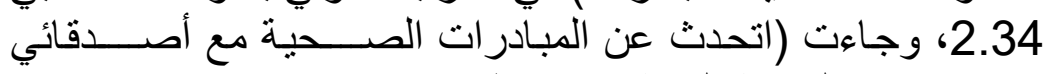

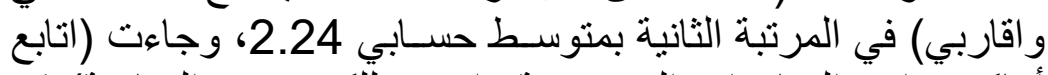

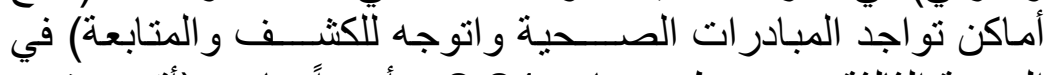

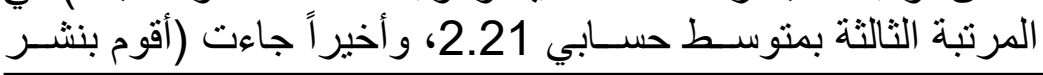


المعلومات الصـحية الخاصـة بالمبادر ات على صـفنتي الثـخصـية) بمتو سط حسابي 1.99 (1.

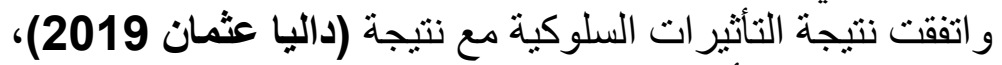

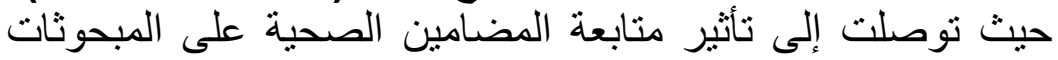

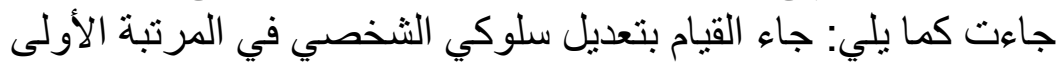

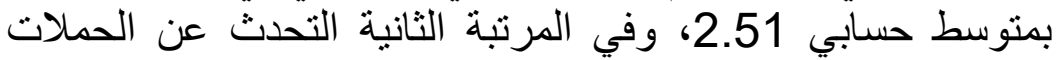

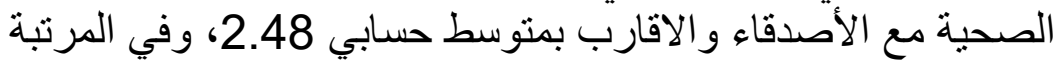
الثالثة متابعة أماكن تو اجد الحملات الصحية و التوجه للكثف و والمتابت وفيعة بمتوسط حسابي 2.44. مقترحات المبحوثين لتطوير المضامين الصحية المقدمة على وسائل التواصل الاجتماعي جدول (8) يوضح مقترحات المبحوثين لتطوير المضامين الصحية المقدمة على المئي

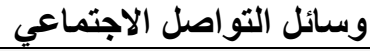

\begin{tabular}{|c|c|c|}
\hline$\%$ & ك & المقترحات \\
\hline 21.7 & 18 & الصدق والدقة والموضو عية في عرض المضامين الصحية \\
\hline 21.7 & 18 & تبيث تخاطب كلو فئات المجتمع المنشورة على وسائل التواصل \\
\hline 19.3 & 16 & الاعتماد على مصادر طبية موثوقة \\
\hline 7.2 & 6 & استفسار ات المو اطنين في المحتوى المنشور وسرعة الاجابة على \\
\hline 4.8 & 4 & 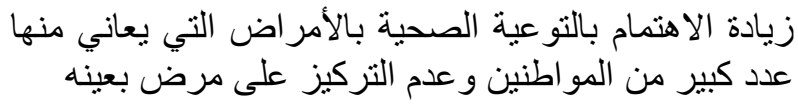 \\
\hline 2.4 & 2 & نشر خلال منابعتها للمضمون استطاعت الصحتشاف عبر وسرضئل التو التغلب عليه \\
\hline 1.2 & 1 & التشجيع المستمر بضرورة الكثف المبكر \\
\hline 100 & 83 & 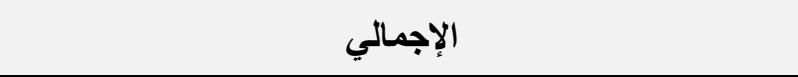 \\
\hline
\end{tabular}

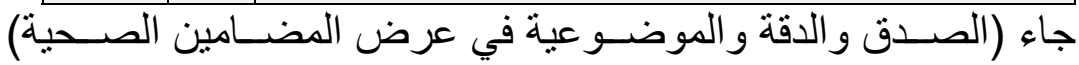

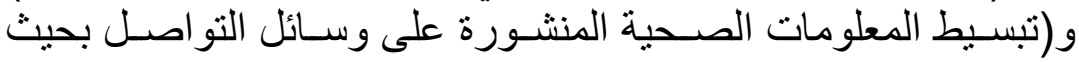

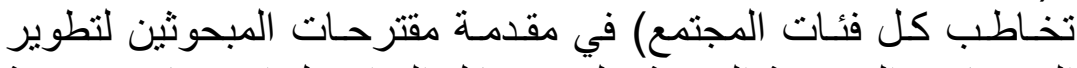

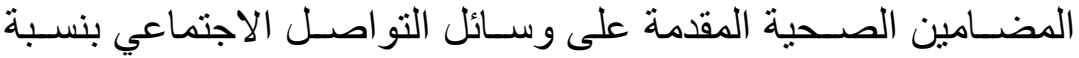

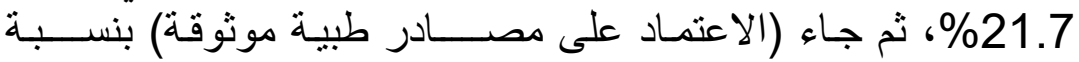

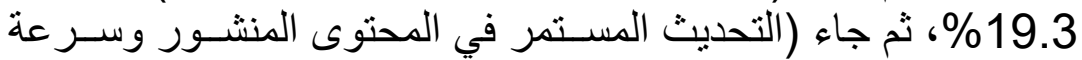

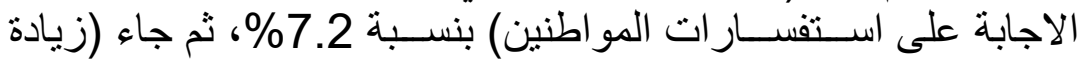




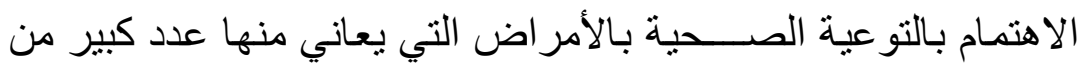

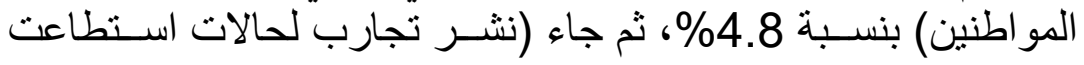

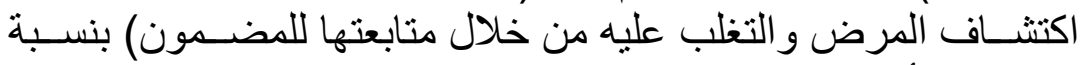

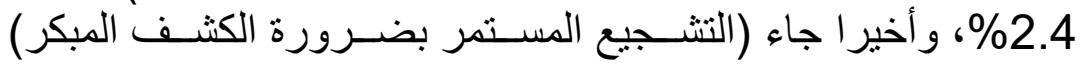
بنسبة 1.2. 11 النتائج العامة للبحث

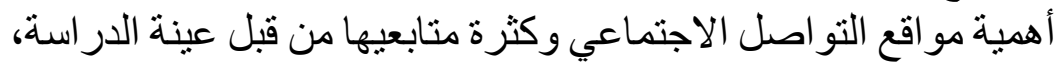

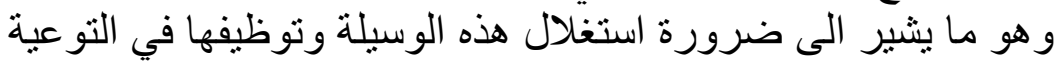
الصحية مما يعزز أهميتها. استخدام الفيس بوك كان هو الأكثر فينان في مواقع التواصل الاجتماعي

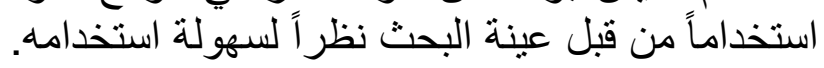

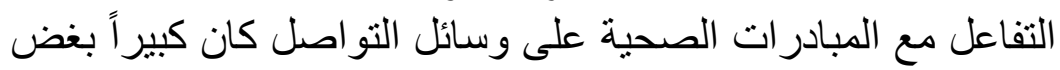

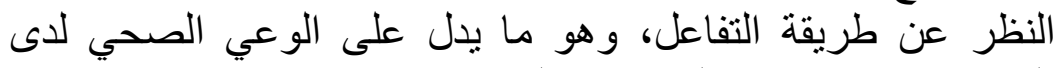
المبحوثين و اهتمامهم بالمبادر ات الفئه الصحية. اهتمت عينة الدر اسة بمتابعة المبادر ات الصات الصحية على وسائل التواصل الصل الاجتماعي بدرجة متوسطة.

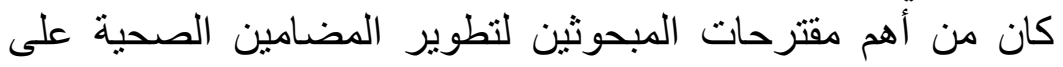

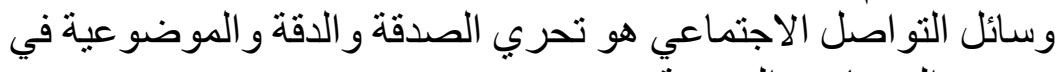
عرض المضامين الصحية. 12

تكثيف حملات التوعية الصحية في وسائل التواصل الاجتماعي،

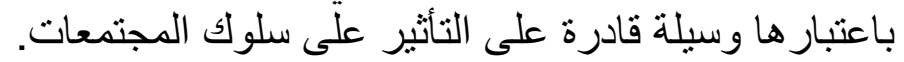

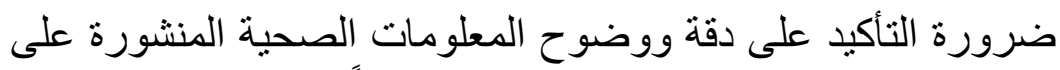

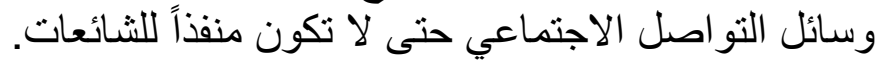

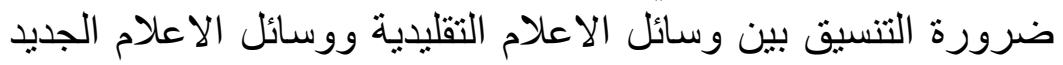

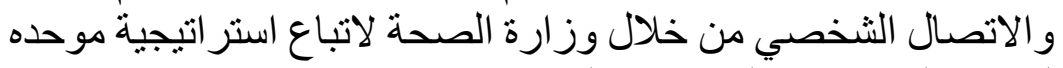
لتو عية المو اطنين بآلمبادر ات الصنية خدية. ضرورة تدريب القائمين على الحملات الصحية لتحقيق الأهداف الصناف الحين المرجوة من الحملة. 


\section{قائمة المراجع \\ أولا: مراجع الأراسة العزة العربية

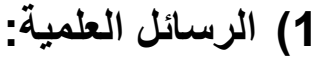

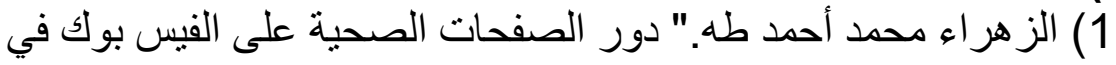

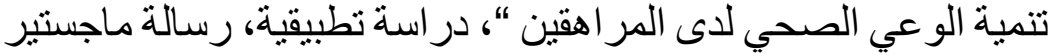

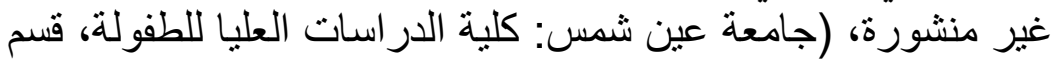

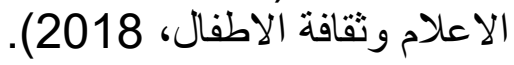

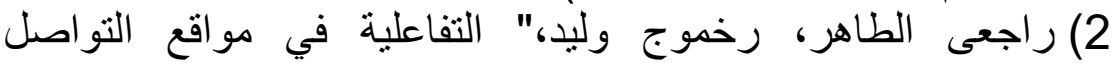

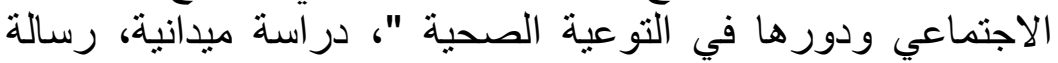

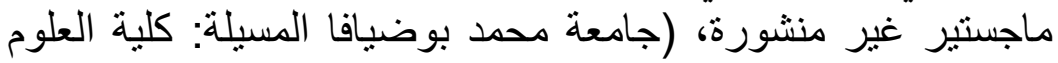

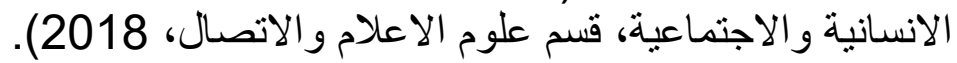

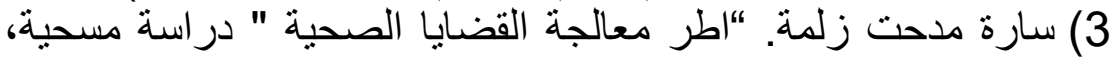

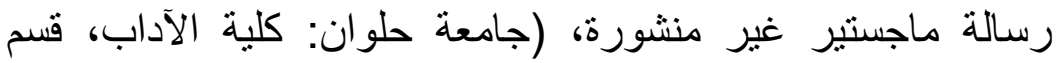

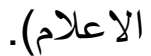
4) لبنى قاسمي، " دور شبكات التو اصل الاجتماعي في التوعية الصحية

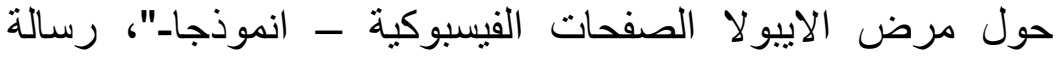

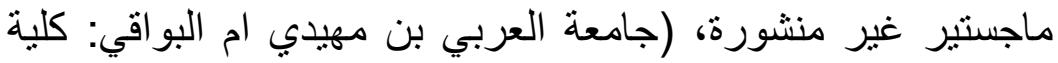

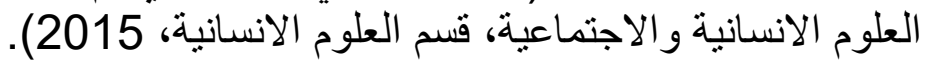

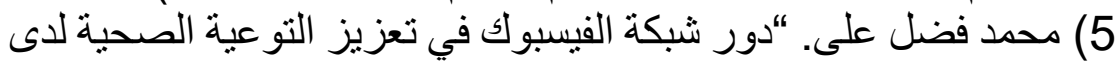

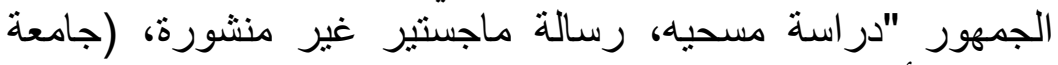

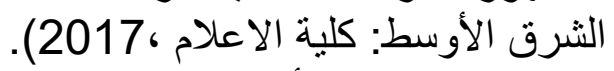

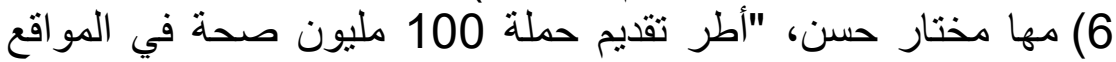
الإخبارية المصرية"، المجلة العربية لبحوث الاعلام و الاتصال، المجلد

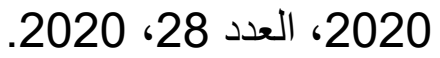
7) نسيبة العلمي، " دور التلفزيون في نشر الوعي الصحي برنامج Dr.Oz

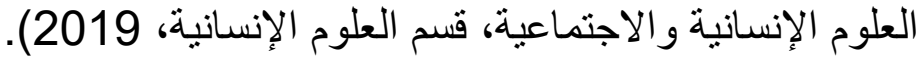

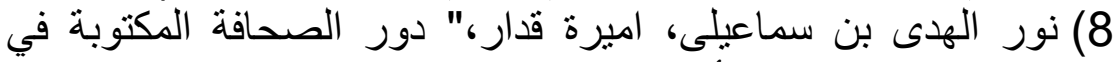

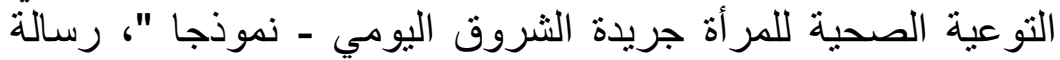

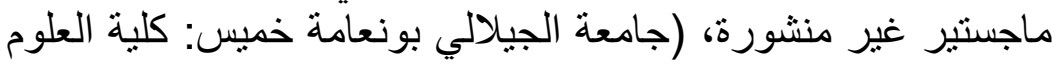

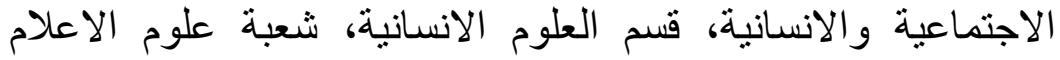

و الاتصال ،2018).

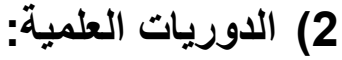
1) إيناس محمود حامد، تعرض الثبات الثباب الجامعي للمبادرات الرئاسية المصرية عبر شبكات التواصل الاجتماعي وعلاقته باتجاهاتهم 
نحوها، (جامعة عين شمس: كلية الدراسات العليا للطفولة، مجلة

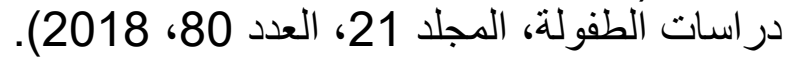

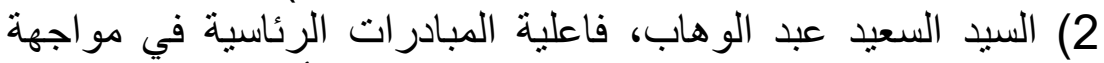

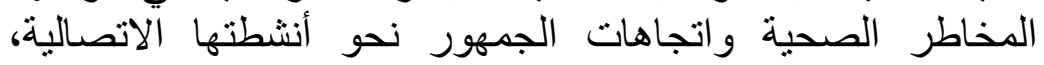
(جامعة القاهرة: كلية الاعلام، المجلة العلمية لبحوث الجات العلاقات العات العامة

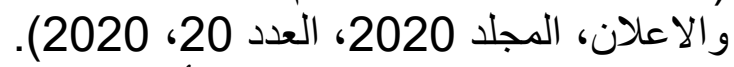

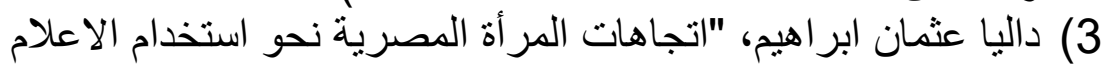

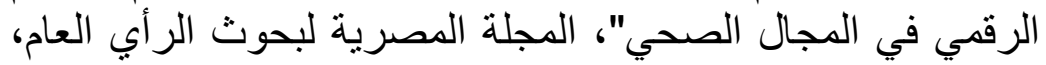
المجلد 18، العدد 3، الريج

4) رشا عبد الرحمن حجازي، دور الحملات الإعلامية في تشكيل الوعي

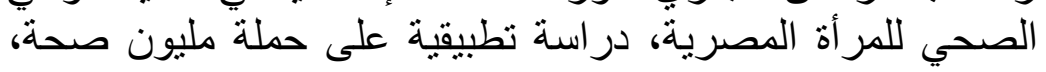

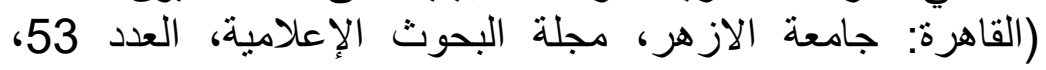

5) شارع بن مزيد البقمي، التأثير المعرفي لحملات التوعية الاكترونية

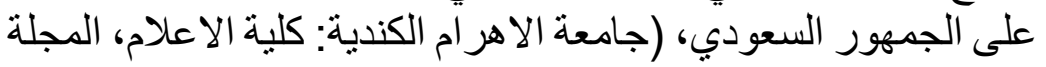
العربية لبحوث الاعلام و الاتصال، العدد 29، 2020، 2020).

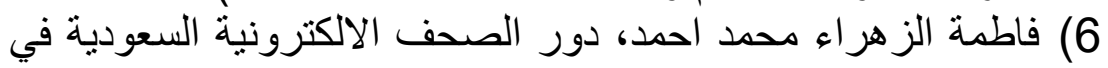

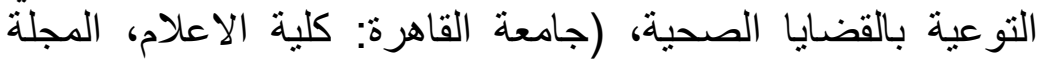
المصرية لبحوث الاعلام، العدد 37، 2011).

1) حسن عماد مكاوي، ليلى حسين:" الاتصال ونظرياته المعاصرة"،

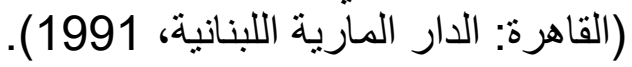
2) سعد سليمان المشهداني، مناهج البحث الإعلامي، ط1، الكي، (الامار ات، دار

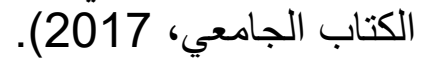

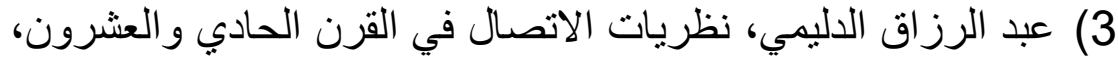

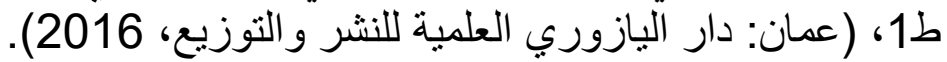

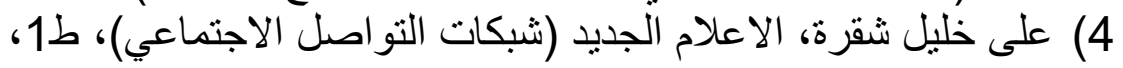

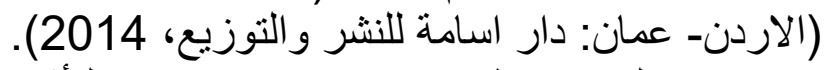

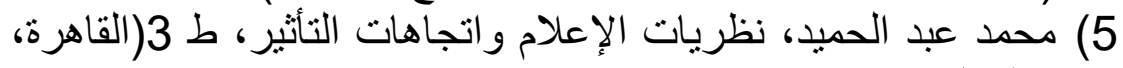

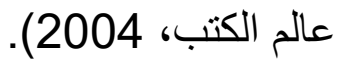
6) محمد منير حجاب: "نظريات الاتصال"، ط1 التمال، (القاهرة: دار الفجر للنشر و التوزيع، منير حجاب: 2010). 7) محمود اسماعيل، مبادئ علم الاتصال ونظريات التأثير، (القاهرة:

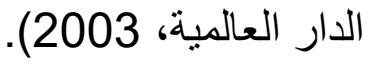


8) مصطفى يوسف كافي، الرأي العام ونظريات الاتصال، ط1 (عمان:

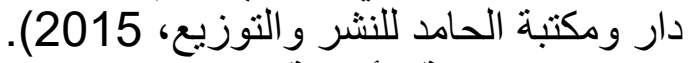
ثانيا: مراجع الداراسة الأجنبية:

1) Mark Miller ،Stephen ‘D. Reese:" Media Dependency as Interaction, Effects of exposure and Reliance on political Activity and Efficacy", Communication Research ‘Vol. 9 ، No.2, April 1982, p.232.

2) Meliven DeFleur \& Sandra Ball-Rokeach, "A dependency Model of Mass-Media Effects", Communication Research, Vol. 3 No.1, 1976, P 9.

\section{ملحق (1) أسماء محكمي استمارة الاستبيان}

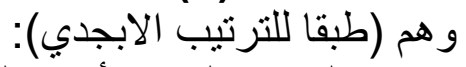

1. أ.د سعيد الغريب النجار : أستاذ الصحافة بكلية الاعلام- جامعة القاهئ الاهرة. 2. أ.د شريف درويش اللبان: أستاذ الصحافة وتكنولوجيا الإتلاتيال كلية الاعلام- جامعة القاهرة. النان. 3. أ.د عبد الهادي أحمد النجار: أستاذ الصحافة بقسم الإعلام كلية الآداب - جامعة المنصورة. 4. أ.م.د محمد جمال محمد عبد المقصودة: أستاذ مساعد بقسم الجر افيكس و الوسائط المتعددة كلية الاعلام و الاتصال - جامعة الامام محمد بن الأن

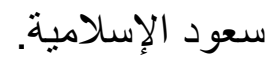

5. ا.م.د منى جابر عبد الهادية هانثم: أستاذ الصحافة السساعد كلية الاعلام- جامعة بني سويف. 6. أ.م.د هيثم جودة مؤيد: أستاذ الصحافة والنشر الإلكتروني المساعد7امعة الزقازيق. 7. أ.د وائل إسماعيل عبد الباري: أستاذ الصحافة بكلية الاعلام- جامعة

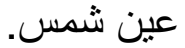


Scientific Journal of Faculty of Arts 10 (3) 2021,

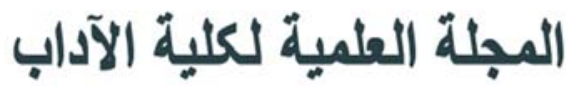

https://artdau.journals.ekb.eg/

\section{The Role of Social Media in Educating Citizens About Health Initiatives}

\section{Hajar Magdy Abdo Al-Hamami}

Master's Student-Department of Media -Faculty of Arts - Damietta University

Abstract

The research aims to identify the degree of citizens' interest in awareness issues of health initiatives on social media, and the cognitive, emotional and behavioral influences that were formed by respondents who follow health initiatives on these means, The research used the sample survey method, and the questionnaire tool to collect data, the research sample represented a simple random sample of the citizens of the Egyptian people (males and females) from each of the following governorates (Greater Cairo, Minya, Damietta), the sample consisted of 400 individuals. The research reached a number of results, the most important of which are: The importance of social networking sites and the large number of their followers by the study sample, which indicates the need to exploit this method and employ it in health awareness, which enhances its importancer (Social networking sites) came at the forefront of the sources that the study sample relied upon to obtain information on health initiatives with a weight of $23.37 \%$ ، The 100 Million Health Initiative came at the forefront of the health awareness campaigns that the respondents followed through social media, with a rate of $83.3 \%$ 'One of the most important cognitive effects of respondents' exposure to health initiatives on communication media (making the users of communication media aware of health initiatives) with an average of 2.58 , and the most important emotional effects (taking caution and caution against contracting a disease) with an average of 2.51, and the most important behavioral effects (I adjust my health behavior according to the initiatives' health information) with a mean of. 2.34 .

Keywords social media ,health initiatives.

Article history:

Received 20 June 2021.

Received in revised form 3 July 2021.

Accepted 15 July 2021. 